\title{
Corrosion of steel in carbonated concrete: mechanisms, practical experience, and research priorities - a critical review by RILEM TC 281-CCC
}

\author{
Ueli Angst ${ }^{a *}$, Fabrizio Moro ${ }^{b}$, Mette Geiker ${ }^{c}$, Sylvia Kessler ${ }^{d}$, Hans Beushausen ${ }^{\mathrm{e}}$, Carmen Andrade ${ }^{\mathrm{f}}$, Jukka \\ Lahdensivu's, Arto Köliö ${ }^{h}$, Kei-ichi Imamoto', Stefanie von Greve-Dierfeld', Marijana Serdark
}

a ETH Zurich, Switzerland, Institute for Building Materials, Zurich, Switzerland

b LafargeHolcim Innovation Center, Saint-Quentin Fallavier, France

c Norwegian University of Science and Technology, Department of Structural Engineering, Trondheim, Norway

d Helmut-Schmidt-University / University of the Federal Armed Forces Hamburg, Chair of Engineering Materials and Building Preservation, Hamburg, Germany

e University of Cape Town, Department of Civil Engineering, Rondebosch, South Africa

$f$ International Centre for Numerical Methods in Engineering, CIMNE-UPC, Barcelona, Spain

g Ramboll Finland Oy, Tampere, Finland

h Tampere University, Department of Civil Engineering, Tekniikankatu 12, 33720 Tampere, Finland

Tokyo University of Science, Department of Architecture, Tokyo, Japan

j TFB AG, Wildegg, Switzerland

k University of Zagreb, Faculty of Civil Engineering, Department of Materials, Croatia

Received: 19 October 2020 / Accepted: 8 December 2020 / Published online: 14 December 2020

(C) The Author(s) 2020. This article is published with open access and licensed under a Creative Commons Attribution 4.0 International License.

This article has been prepared within a framework of RILEM TC 281-CCC. The article has been reviewed and approved by all TC members.

\begin{abstract}
Carbonation of concrete is in the concrete and cement research community often assumed to lead to reinforcing steel corrosion. This mindset has long dictated the research priorities surrounding the developments towards low-emission binders. By reviewing documented practical experience and scientific literature, we show that this widely held view is too simplistic. There are many cases from engineering practice where carbonation of the cementitious matrix surrounding the steel did not lead to noticeable corrosion or related damage at the level of a structure. The influencing factors that can, however, lead to considerable corrosion damage are identified as the moisture state, the microstructure of the carbonated concrete, various species that may be present - even in minor amounts - in the concrete pore solution, and the cover depth.

The circumstance that a reduced $\mathrm{pH}$ alone is not sufficient to lead to significant steel corrosion in concrete seriously challenges the established approach of assessing the durability performance based on carbonation testing and modeling. At the same time, this circumstance offers great opportunities for reducing the environmental impact of concrete structures with low-emission binders. To realize these opportunities, the focus in research and engineering should shift from studying carbonation to studying corrosion of steel in carbonated concrete.
\end{abstract}

Keywords: Carbonation; Corrosion; Cracking; Durability; Sustainability

\section{Introduction}

Carbonation of concrete has received research attention almost 100 years ago $[1,2]$ with a marked increase over the last decades (Fig. 1b). This increase in scientific studies can primarily be related to the development of a growing variety of "modern" cementitious binders. Many of these cements have the potential to offer environmentally-friendly (low $\mathrm{CO}_{2}$ emissions) and sustainable alternatives to traditional cements, given that the structure for which the cement-based material is used for is durable over its entire design service life. However, these modern cements generally have a lower carbonation resistance due to the lower $\mathrm{pH}$ buffer capacity than cements forming high amounts of Portlandite.

For successful application of cementitious materials in construction of reinforced concrete (RC), the question is not if the concrete carbonates, but if this carbonation ultimately leads to relevant damage of the structure. The process of carbonation of cementitious materials may have various beneficial and adverse effects. For instance, carbonation removes $\mathrm{CO}_{2}$ from the atmosphere [3] and can improve mechanical properties of the concrete, at least for Portland cement [4]. On the other hand, carbonation may negatively

* Corresponding author: Ueli Angst, Email: uangst@ethz.ch 
influence the freeze-thaw resistance or shrinkage behavior of the concrete $[5,6]$. One of the most frequent concerns of carbonation is that the resulting decrease in $\mathrm{pH}$ presents a risk for corrosion of the reinforcing steel.

Figure 1a summarizes the sequence of the involved, coupled processes, starting with carbonation of the cover concrete (A) which may - under some conditions - lead to loss of steel passivity (B), which in turn may - under some conditions lead to active corrosion (C). Finally, this steel corrosion process may - again under some conditions - lead to damage at the structural level (D). Figure $1 \mathrm{~b}$ illustrates that the different involved processes have not received comparable attention in research over the last decades. In fact, by far most of the research addressed carbonation of the cementitious phases and only a minor number of studies have looked into the related corrosion processes. Even more stunning is the fact that only a negligible number of studies have documented practical experience of the conditions under which carbonation of the concrete surrounding the reinforcing steel has led to structural damage.

This lack of knowledge, in particular the lack of quantification of corrosion rates after depassivation, has major implications for the sustainable and cost-efficient use of low-emission binders. Current approaches in standardization and durability design are largely based on the strategy of "avoiding carbonation of the concrete cover" (step A in Figure 1a) rather than "avoiding corrosion" (step C) or "avoiding damage" (step D). This current concept is for instance reflected by test methods for "carbonation resistance" used as durability indicators in some countries. To some extent, however, standards already implicitly consider that carbonation does not always lead to corrosion and damage, as is apparent from the low cover depth requirements in moderate humidity exposure conditions (taking the European standards as example, this corresponds to exposure class XC3, Table 1). While this empirical approach may work for XC3, for durability design in wet/dry exposures (XC4), on the other hand, taking into account the corrosion propagation phase cannot be done in an empirical manner, but needs fundamental quantification of the relevant processes.

It is the motivation of this paper to elaborate under what conditions carbonation of reinforced concrete leads to corrosion and corrosion-induced damage at the structural level. To this aim, we review documented experience from engineering practice and rationalize these observations on the basis of state-of-the-art scientific understanding, identifying the underlying mechanisms and the controlling factors.

\section{Corrosion-related damage of RC structures - a short review of possible limit states}

Corrosion-related damage of RC may come into effect through different mechanisms, as reinforcement corrosion may impair the structural serviceability and load bearing capacity in different manners.

a) Sequence of processes leading to carbonation-induced damage to $\mathrm{RC}$ structures

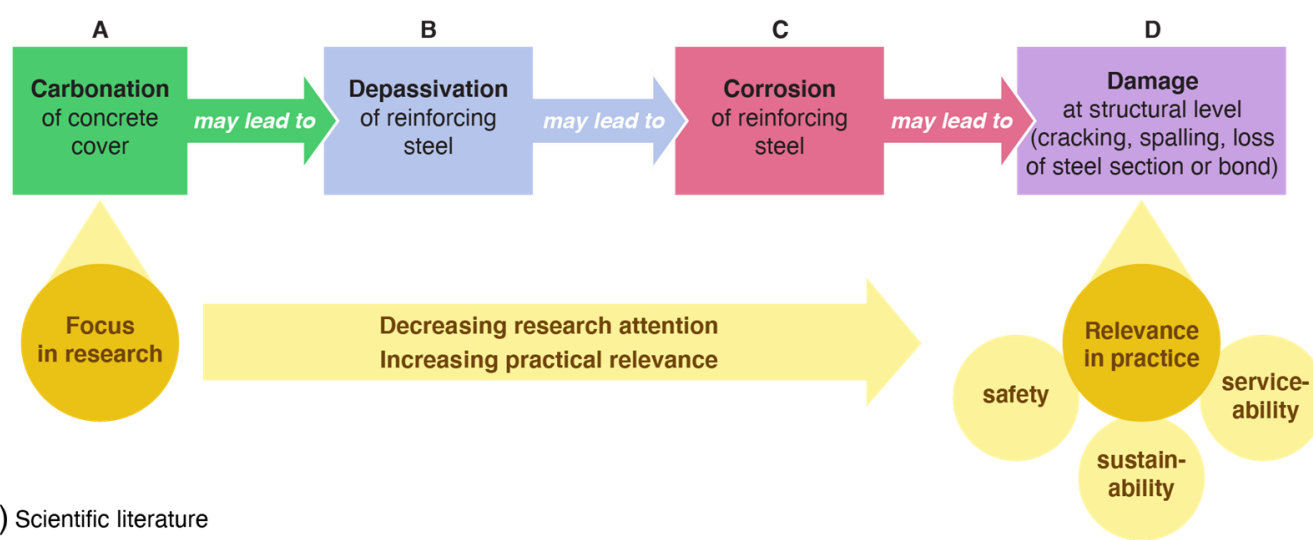

b) Scientific literature

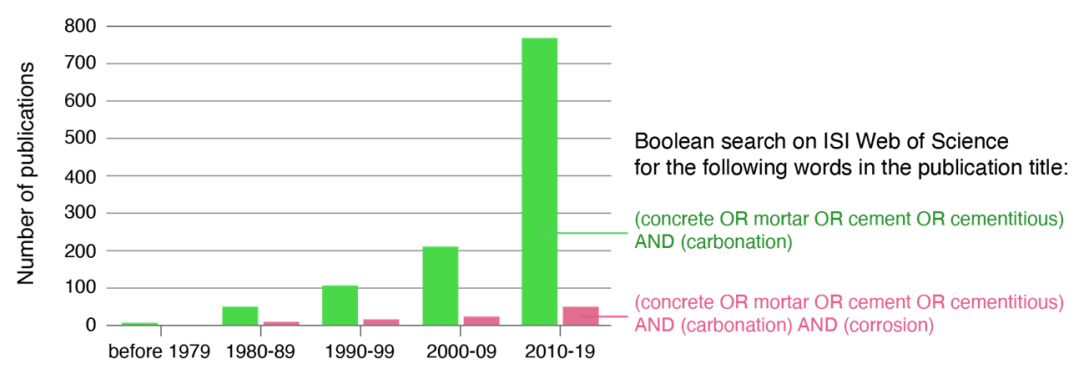

Figure 1. a) Coupled processes leading to carbonation induced damage to reinforced concrete structures; b) Research attention illustrated by a Boolean search on ISI Web of Science, revealing that by far most of the scientific literature regards carbonation of the concrete, while only relatively few studies addressed steel corrosion in carbonated concrete. Moreover, it should be noted that even though "corrosion" appears in the title of some publications, there is no guarantee that corrosion is in fact addressed in the publication.

Table 1. Exposure classes for carbonation induced corrosion and related concrete cover requirements in the European standards $([7,8])$ 


\begin{tabular}{|l|l|l|l|}
\hline $\begin{array}{l}\text { Exposure } \\
\text { class }\end{array}$ & Description & Examples & $\begin{array}{l}\text { Minimum } \\
\text { cover* }\end{array}$ \\
\hline XC1 & Dry or permanently wet & Indoor with low air RH or permanently submerged & 15-20 mm \\
\hline XC2 & Wet, rarely dry & Long-term water contact (e.g. foundations) & $25-30$ mm \\
\hline XC3 & Moderate humidity & $\begin{array}{l}\text { Indoor with moderate or high air RH, external concrete sheltered from } \\
\text { rain }\end{array}$ & $25-30$ mm \\
\hline XC4 & Cyclic wet and dry & Periodic contact to water (e.g. facades, balconies) & $30-35$ mm \\
\hline
\end{tabular}

* For structural classes S4 and S5 and service life 50 years, in combination with requirements for concrete composition and compressive strength according to EN206

\subsection{Rust staining and cracking and spalling of the concrete cover}

The formation of insoluble corrosion products that precipitate in the concrete pore system may lead to expansive stresses and cause cracking and spalling of the concrete cover [9]. Moreover, the corrosion products may appear at the concrete surface in the form of red-brown rust stains.

Rust staining and concrete surface cracking and spalling are undesirable for a number of reasons. For instance, it is not tolerable if concrete pieces spall off and fall down on areas frequented by pedestrians or traffic. Moreover, cracking and spalling are a degradation of the protective concrete cover and generally impair the durability and fire-resistance of the structure. It should be noted, however, that these consequences of the corrosion damage, namely cracking and spalling, are primarily serviceability issues and will generally not immediately compromise the structural load bearing capacity.

\subsection{Loss of bond at the steel-concrete interface}

Different processes resulting from rebar corrosion may affect the bond between steel and concrete: On the one hand the sectional loss of the corroding rebars (gradually eliminating the ribs on the surface and widening the interspace between steel and concrete) likely reduces the bond at the steelconcrete interface. On the other hand, the filling of the voids at the $\mathrm{SCl}$ with corrosion products may to some extent compensate for the sectional loss effects. In this regard, Cabrera [10] showed that the bond strength first increased (by approx. 20\%) with degree of corrosion (up to 2-3\% weight loss on $12 \mathrm{~mm}$ diameter bars, which corresponds to approx. $0.1 \mathrm{~mm}$ of corrosion attack), after which further corrosion caused a significant reduction in bond strength. Very similar results were also obtained by others, e.g. [11]. However, in these studies corrosion was accelerated (chloride solution and/or impressed current), and thus, the results should be applied to practical conditions with caution $[12,13]$. Further data revealing similar trends can be found in [14]. In short, it appears that substantial corrosion attack of the steel is needed (above $0.1 \mathrm{~mm}$ ) to lead to a reduction in bond strength. Finally, at later stages in the corrosion propagation stage, the bond may also be affected as the result of concrete cracking and spalling.

\subsection{Reduction of reinforcing steel sectional area}

The corrosion process leads to a loss of solid metal and thus to a reduction of cross sectional area of the corroding steel. In principle, a reduction in steel sectional area will impair the stiffness and ultimately the load-bearing capacity of RC structural members. This requires substantial corrosion rates over prolonged time, which rarely occurs in carbonated concrete as will be shown later in this review.

\subsection{Relevant limit state in engineering practice}

The sectional loss of the rebar due to carbonation-induced corrosion (in the absence of chlorides) is generally not considered a relevant limit state, because - as will be shown in this review - the observed sectional losses are typically found too small to significantly impair the load-bearing capacity or the stiffness of the structure. Before sectional loss becomes relevant, extensive concrete cover cracking and spalling occur. Thus, carbonation-induced corrosion is primarily considered a serviceability issue.

\section{Review of documented cases from engineering practice}

\subsection{Common practice of condition assessment}

The common practice used in inspecting structures is typically based on a first visual assessment of the structure, especially the concrete surface. Rust stains, cracks and areas of spalling are documented. Moreover, in the case of carbonation exposure conditions, it is common to determine the carbonation depth with the help of indicator solutions (phenolphthalein or lately thymolphthalein), and to assess the degree of corrosion attack at the reinforcing steel, generally through local removal of the concrete cover and visual assessment of the steel. A delamination survey (e.g. hammer tapping) can further assist with identifying corrosion-damaged areas that have not started to show any signs of damage on the surface. These engineering practices are well-documented in national and international standards and guidelines [15-17]. The measurement of additional parameters such as electrochemical potential, electrical concrete resistivity, or instantaneous corrosion rates on-site is comparatively rare for carbonated structures.

The measurement of carbonation depths further allows the estimation of carbonation coefficients specific to the concrete and prevailing exposure conditions. In combination with cover depth measurements, this may then be used to predict the remaining time until carbonation reaches the steel.

These inspection practices determine the sort of data that is available for the present review as presented in the following. Note that in this section, only experience from engineering structures (ensuring practice-related materials and exposure 
conditions) is considered. Knowledge from laboratory and theoretical studies is considered in section 4 .

\subsection{Depassivation and initiation of corrosion in carbonated concrete}

There are many documented cases where the carbonation depth has approached, reached or exceeded the reinforcing steel depth and where the reinforcing steel shows signs of corrosion. A typical example is shown in Fig. 2a. However, there are also cases such as the one shown in Fig. $2 b$ where, despite the steel being surrounded by carbonated concrete, no signs of corrosion can be visually seen on the rebar. In both cases, the carbonation depth had clearly exceeded the cover depth, suggesting that by the time of inspection, the steel had been surrounded by carbonated concrete already for a significant time, at least several years. Figure 2a shows a mild degree of reinforcement corrosion, with little to no appreciable damage to the steel surface. While corrosion in carbonated concrete is generally less aggressive and destructive to the steel compared to chloride-induced corrosion, it needs to be noted that carbonation-induced corrosion can, in some cases, also result in significant damage to the steel over time (Fig. 2c). These examples highlight that the reduced $\mathrm{pH}$ in carbonated concrete alone is not sufficient to lead to reinforcement corrosion, and that other factors play an important role in potentially promoting corrosionrelated damage in carbonated concrete.

\subsection{Corrosion rate}

Since corrosion rates can vary greatly over time, we distinguish between instantaneous corrosion rates (e.g. measured at a single point in time) and average corrosion rates (averaging the temporal variability over extended time periods, such as a year) [18].

Data on instantaneous corrosion rates in carbonated concrete are available in the database of Geocisa [19], which contains more than 3000 independent measurements of instantaneous corrosion rates for steel in carbonated concrete structures. Out of these data, $80 \%$ are values below $1 \mu \mathrm{m} / \mathrm{y}$, and about $98 \%$ are values below $10 \mu \mathrm{m} / \mathrm{y}$. Only in very rare cases were higher corrosion rates measured, with a maximum of less than $100 \mu \mathrm{m} / \mathrm{y}$. In agreement with this, Rebolledo et al. [20] reported instantaneous corrosion rates around 1-5 $\mu \mathrm{m} / \mathrm{y}$ in two carbonated structures in Spain, and Revert [21], based on the inspection of a purification plant in the southern part of Norway estimated average corrosion rates of $1-3 \mu \mathrm{m} / \mathrm{y}$.

Further data are available from facades and balconies in Finland [22, 23]. It should be mentioned, however, that the instantaneous corrosion rate measurements (with electrochemical techniques) were not performed directly on rebars in the structures, but on installed sensors. These sensors consisted of steel electrodes (diameter $4 \mathrm{~mm}$ ) located at cover depths 5,10 , and $15 \mathrm{~mm}$. The surrounding concrete was produced from Portland cement, with high w/c of 0.8, and carbonated at $4 \% \mathrm{CO}_{2}$ prior to being installed on the structures. The measurements clearly showed the impact of the exposure conditions and yearly variations. The balcony sidewalls that were directly exposed to wind-driven rain (XC4) showed up to 10 times higher corrosion rates than the bottom of the balcony slabs (sheltered, XC3). For structural members exposed to rain, the corrosion rates varied considerably over time, namely in the range $0.5 \mu \mathrm{m} / \mathrm{y}$ (dry periods) to $30 \mu \mathrm{m} / \mathrm{y}$ (wet periods, wind-driven rain exposure). The yearly average was between 3 and $15 \mu \mathrm{m} / \mathrm{y}$. It should be noted that the cover depth was very low and the concrete was relatively porous $[22,23]$ with respect to what standards would prescribe (e.g. Table 1). Thus, the recorded peak corrosion rates during wet phases can be considered relatively high.

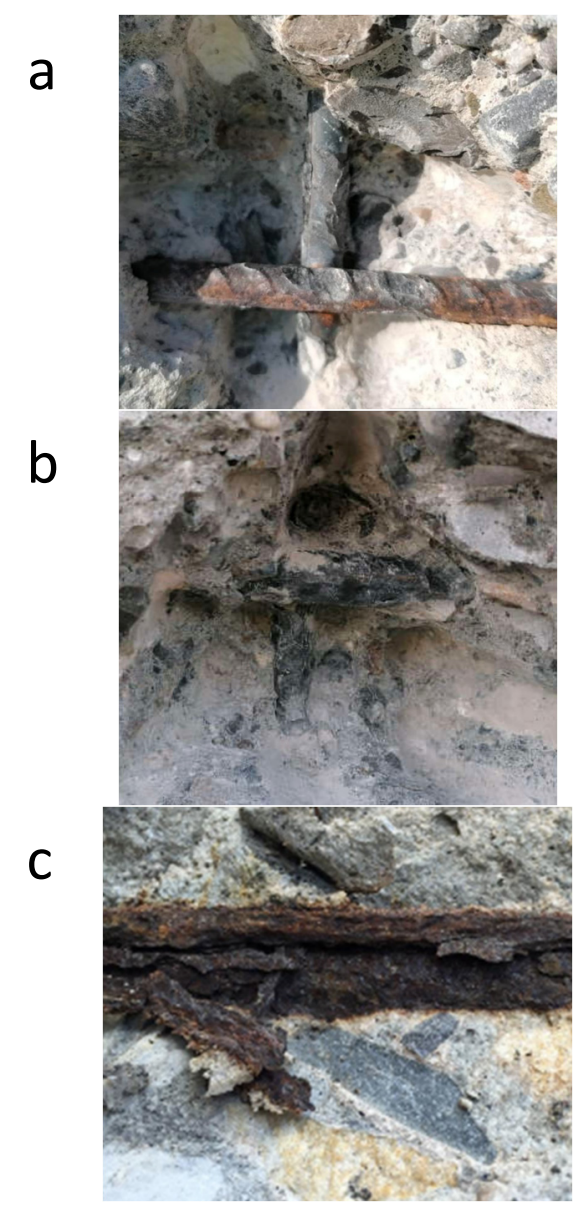

Figure 2. Examples of reinforcing steel visually inspected upon local removal of concrete during the assessment of reinforced concrete structures. a,b) Facades of storage buildings in Switzerland. In both cases shown, the cover depth was $22 \mathrm{~mm}$, the carbonation depth was 33-38 $\mathrm{mm}$, and the rebar diameter was $8 \mathrm{~mm}$. In a) the rebar was slightly red/brown indicating corrosion initiation, while in b) there are no signs of corrosion at all. (Photographs, courtesy of Ueli Angst); c) Example of significant damage to the reinforcing steel as a result of carbonation-induced corrosion on a bridge abutment in South Africa (photograph courtesy of Hans Beushausen).

Finally, the observations from ancient buildings reported in [24] should be mentioned. In this work, 20 historical artefacts from different structures, ranging in age between 80 and 1700 years, were analyzed. The samples consisted of iron or steel embedded in various cementitious binders. While the youngest sample was a contemporary concrete (found to be "at least partially carbonated"), some of the older samples 
consisted mainly of calcite and the $\mathrm{pH}$ of these binders was reported to be around 8 . Based on microscopic analyses of the corrosion product layers, the average corrosion rates were estimated at $2 \mu \mathrm{m} / \mathrm{y}$. While little information is available about the damage caused to the surrounding cementitious matrix, the study indicates that the corrosion process of steel in carbonated binders exposed to the environment over long times is very slow.

These empirical findings are also reflected by the (averaged over time) corrosion rates indicated in the Duracrete guidelines [25] that are of the order of $5 \mu \mathrm{m} / \mathrm{y}$ for XC4 exposure class.

\subsection{Damage at the structural level}

Imamoto et al. [26] reported observations from 21 reinforced concrete buildings in Japan. Figure 3 shows the results of the visual assessment of the reinforcing steel bars. For the purpose of the present paper, similar data from inspections of Swiss concrete structures was collected. This data came from $>40$ structures, comprising 195 local inspections. It is important to note that Figure 3 only considers cases where the carbonation depth had already reached the steel depth. Despite the steel being surrounded by carbonated concrete in all these cases, no signs of corrosion were found on the rebars in a substantial portion (approx. 10-30\%). A further substantial portion (approx. 50-70\%) of the evaluated structures showed only slight signs of corrosion. These typically include a few rust spots or superficial rust that does not mean relevant damage to the engineering structure. The most remarkable result in Fig. 3 is that only in about $10-15 \%$ of all these structures, relevant corrosion damage was apparent on the examined steel surfaces. There was no systematic correlation between the age of the structure and the degree of damage.

Figure 4 reports results from visual assessments of concrete surface of structures in Finland. These data were collected in a study by Lahdensivu [27], in which pre-cast concrete element buildings constructed between 1961 and 1996 were inspected after $15-50$ years. The data are here re-analyzed for the purpose of this review. Figure 4 details the fraction of carbonated structures showing no, local, or widespread damage. Similar to Figure 3 , widespread damage was only found in a minority of cases $(<20 \%)$, although the reinforcing steel had been in carbonated concrete for some time.

In analyzing these observations, the investigators of the Swiss, Japanese, and Finnish structures came up with very similar explanations. First, damage only occurred in situations of low cover depth in combination with high moisture conditions. For vertical elements such as facades or balcony side walls, "high moisture conditions" occurred for exposure to winddriven rain (XC4). For the balcony soffits (sheltered from rain, in principle XC3), the observed local damage could be explained by the local access to water due to the water drainage system, which consisted of a gap between the balcony slab and the parapet. This detailing (common in the 1970s) allowed rain flowing along the surface of carbonated concrete of the balcony slab. For the structures in Finland, it was clearly concluded that many of the observed cases of damage were correlated to low cover depths. According to the Finnish building regulations the cover depth of reinforcement should for all inspected structures have been min. $20 \mathrm{~mm}$, even in the buildings built in 1970s. However, due to insufficient quality control, $20-40 \%$ of the cover depths were less than $20 \mathrm{~mm}$.

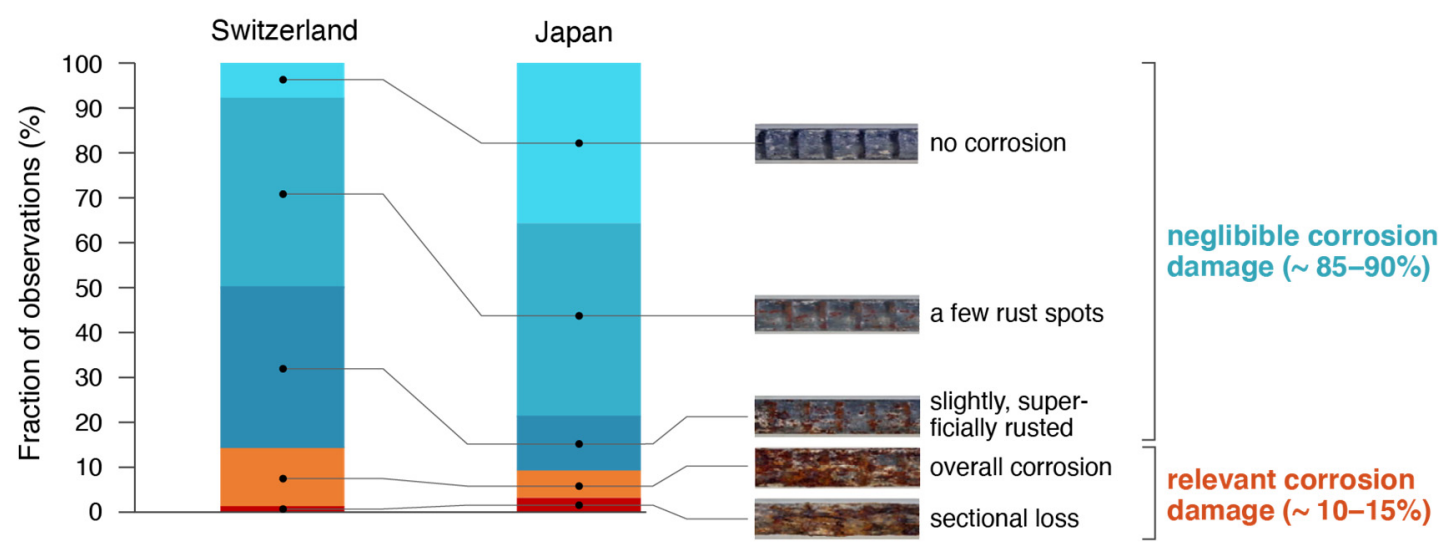

Figure 3. Observations from concrete structures, summarizing the visually apparent damage at the rebar surface upon inspection. Only cases where the carbonation front had already reached or exceeded the rebars at the time of inspection were considered. Despite this, relevant corrosion was only found in a minority (10-15\%) of the cases. Based on 195 observations from Switzerland (so far unpublished data) and 21 observations from Japan [26], based on criteria of the Japan Concrete Institute). Age of the structures 20-100 years. Swiss data mostly based on Portland cement, Japanese data including slag cement. 


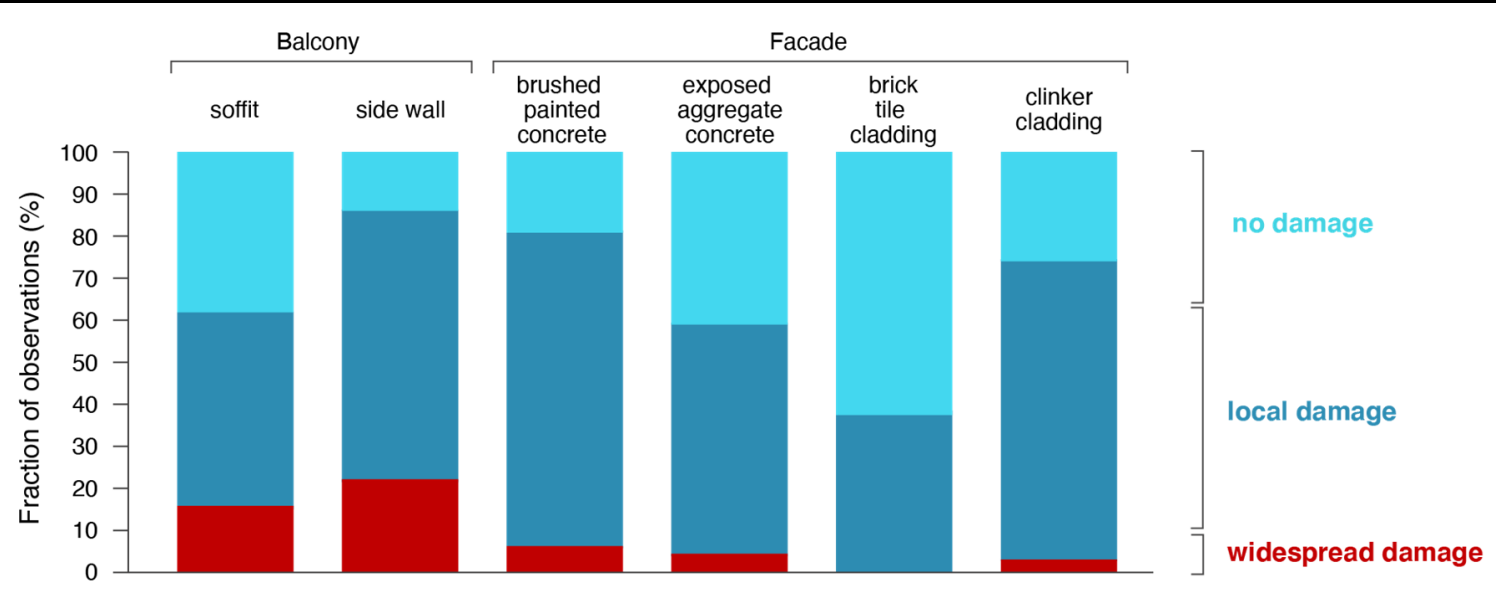

Figure 4. Observations from Finnish concrete structures, summarizing the visually apparent damage at the concrete surface upon inspection. Local damage $=$ few cracks, e.g. at corners or close to water drainage gap; widespread damage = cracking and spalling. Only cases where the carbonation front had already reached or exceeded the rebars at the time of inspection were considered. Despite this, widespread corrosion was only found in a minority of the cases. Based on 793 inspected structures, age approx. 15-50 years, generally Portland cement [27].

A further analysis of the inspection results from the Finnish concrete facades (Fig. 5) illustrates the importance of the concrete cover in limiting damage. Spalling was only observed at very shallow cover depths $(<10 \mathrm{~mm})$, irrespective of rebar diameter and of the duration of corrosion propagation ( $\left.t_{\text {corr }}\right)$.

In agreement with this, Su et al. [28] reported the inspection of a large 75 years old carbonated concrete structure. It was concluded that corrosion-induced concrete spalling only occurred in zones where the cover depth was below $25 \mathrm{~mm}$. Despite carbonation, areas with larger cover depths were described as "sound", irrespective of the exposure direction with respect to rain and wind. Already Hamada [2] observed that corrosion damage in carbonated concrete correlated with exposure to rain and wind. Today, the importance of humidity in corrosion of steel in carbonated concrete is well acknowledged, as reflected in textbooks and reports such as Refs. $[29,30]$. The importance of moisture is also reflected in the exposure dependent requirement in standards (Table 1). However, as claimed in this paper, the understanding of the role of moisture is not yet used to facilitate sustainable design of reinforced concrete structures.

\section{Mechanisms}

\subsection{Depassivation and initiation of corrosion in carbonated concrete}

The term "corrosion initiation" is in this review, and likely also in many other published documents, understood as the transition from a stable passive state to a state where active corrosion is not only possible, but also occurs at a certain minimum rate to lead to at least some signs of corrosion, e.g. rust spots on the rebar (see Fig. 2a and Fig. 3). Figure 1 schematically showed the corresponding sequence of processes occurring, i.e. from carbonation (A), over depassivation (B), to corrosion (C).

This transition is generally explained by the loss of thermodynamic stability of the passive film on the steel upon a shift of the $\mathrm{pH}$ towards less alkaline values. Figure 6, however, shows that at electrochemical potentials of reinforcing steel generally observed in atmospherically exposed structures, passivity is thermodynamically still stable even at comparatively low $\mathrm{pH}$ values such as around 8. To explain carbonation-induced corrosion, additional factors have thus to be considered.
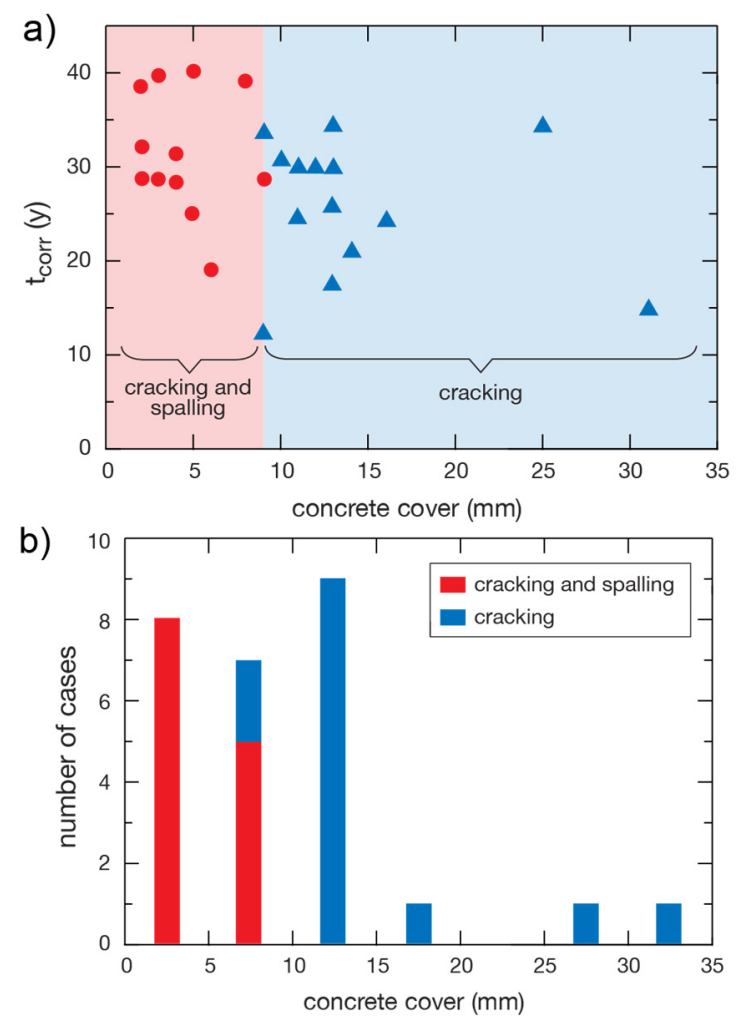

Figure 5. Visual inspection of concrete facade panels in Finland (age 29-37 years). Rebar diameters spanned between 3 and $12 \mathrm{~mm}$, cover depth between 2 and $31 \mathrm{~mm}$. a) $t_{\text {corr }}$ is the time from when the carbonation front had reached the steel until the inspection (based on core samples). . Circles = concrete spalling; triangles = concrete cracking. b) number of cases vs. concrete cover depth. 
A common additional influencing factor is the presence of chlorides, even at low concentrations. It is well known that chlorides destabilize the passive film, and it is generally recognized that the ratio of chloride to hydroxyl ions, $\mathrm{Cl}^{-} / \mathrm{OH}^{-}$ , plays an important role [31, 32]. A decrease of $\mathrm{pH}$ will significantly raise the $\mathrm{Cl}^{-} / \mathrm{OH}^{-}$ratio [33, 34]. This behavior is on the one hand due to the decrease in $\mathrm{OH}^{-}$concentration, on the other hand due to the release of bound chlorides upon carbonating the cementitious phases (for instance, due to the decomposition of Friedel's salt). Figure $6 \mathrm{~b}$ shows an example illustrating the increase of $\mathrm{Cl}^{-} / \mathrm{OH}^{-}$during carbonation of a Portland cement mortar containing admixed chloride. The threshold $\mathrm{Cl}^{-} / \mathrm{OH}^{-} \sim 1$, which is generally assumed sufficient for corrosion initiation [33, 34], is at $\mathrm{pH} 12$ already exceeded by approx. 1 order of magnitude. In addition to an increase in $\mathrm{Cl}^{-}$concentrations, elevated sulphate and bicarbonate concentrations in the pore solution of carbonated concrete may play a role in the destabilization of the passive layer [34, 35].

a)

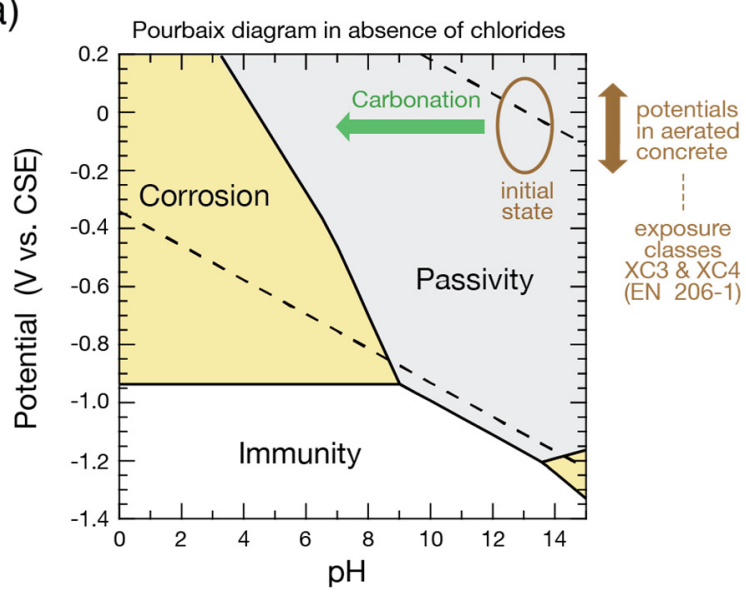

b)

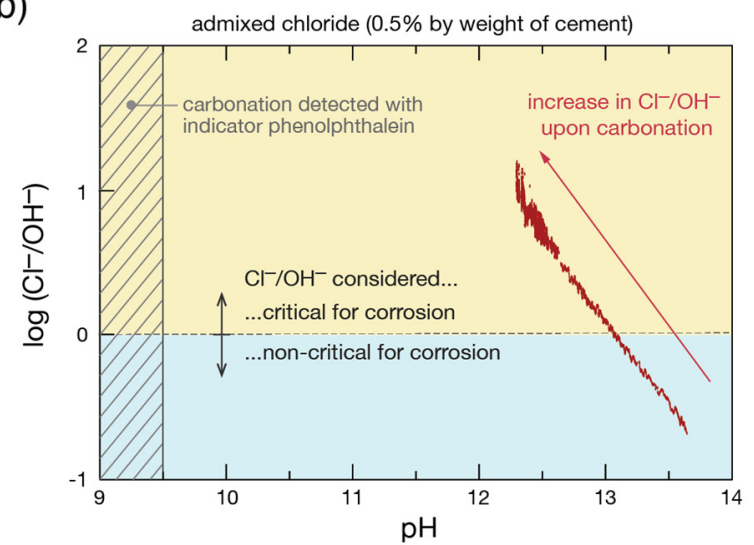

Figure 6. a) Pourbaix diagram (valid for ferrous ion concentration of $10 \mathrm{E}-6 \mathrm{~mol} / \mathrm{l}$, ambient temperature and pressure and the absence of chlorides or other ions), illustrating that passivity is under these conditions still stable at electrochemical steel potentials expected in aerated concrete structures (exposure classes XC3, XC4) even upon carbonation. b) change of $\mathrm{Cl}^{-} / \mathrm{OH}^{-}$ratio (red arrow), measured with combined $\mathrm{pH}$ and chloride sensors embedded in a Portland cement based mortar exposed to carbonation under laboratory conditions (adopted from [33]).
Thus, even at very low chloride contents in the concrete, well below the admissible numbers stipulated in standards such as EN 206-1 [8], the $\mathrm{Cl}^{-} / \mathrm{OH}^{-}$ratio will rise upon carbonation and may easily become the cause for destabilizing the passive film (depassivation) at $\mathrm{pH}$ values still above those that can be detected with indicators such as phenolphthalein. This may explain the observation that corrosion occasionally initiated "ahead" of the carbonation front, as reported in the literature [36].

Another effect promoting depassivation at $\mathrm{pH}$ values around 8-9 may be the formation of small galvanic cells. This is supported by the view that corrosion of metals in meso-tomacro-porous media is a non-uniform process at the microscopic scale [37]. The complexity of the steel-concrete interface [38] gives rise to local heterogeneities in water presence at the steel surface, and may thus promote local differences in $\mathrm{pH}$ and oxygenation (similar to the "Evans drop" [39]).

Finally, the discrepancies found in the literature between the location of the carbonation front and corrosion might - in some cases - be explained by the variability of the carbonation depth. In particular, spatial variation of the carbonation depth was reported in the vicinity of the reinforcement, giving rise to discrepancy between carbonation in the reinforced specimens and in companion unreinforced specimens often used for determination of carbonation depth in laboratory investigations [40]. The geometrical impact of embedded steel on carbonation penetration was also observed by Köliö et al. [41], who reported deeper carbonation depths close to the reinforcement in in-situ exposed concrete.

It is important to note that the review of practical experiences in section 3 revealed that carbonation does not always lead to corrosion (see Fig. $2 \mathrm{~b}$ and Fig. 3). In the example shown in Fig. $2 b$, the measured carbonation depth was so clearly beyond the reinforcement that the explanation of local variability of the carbonation front can be excluded. In the cases summarized in Fig. 3, a third of the structures where the carbonation depth had reached the steel did not show any signs of corrosion. Thus, there must be conditions under which, even upon carbonation (step A in Fig. 1) depassivation does not happen (B) or no active corrosion occurs (C) so that no rust is generated on the steel surface.

\subsection{Corrosion rate}

\subsubsection{Fundamental processes controlling the corrosion rate of steel in cementitious media}

Many studies have revealed the dominating role of moisture in the electrochemical process of corrosion of steel in carbonated concrete (Fig. 7). This knowledge has also entered textbooks [29] and to some extent standards (Table 1). A number of studies showed that the instantaneous corrosion rate in carbonated concrete increases exponentially with the relative humidity in the concrete [42-46]. This relationship was recently explained by the dual role of the pore structure of the cementitious medium surrounding the embedded steel [37]. First, the pore structure governs the amount of water 
that is held in the pore system when in equilibrium with a given exposure moisture condition. The internal concrete moisture content controls the amount of water present at the steel surface, which leads to the concept of the "electrochemically active steel area". This concept essentially means that in dry concrete, only a minor fraction of the steel area is in contact with liquid water and thus most of the steel cannot corrode at significant rate, while in wet concrete, this area fraction increases and leads to higher corrosion currents [46]. Second, the pore structure controls the rate at which ferrous ions, released at the rebar surface in the anodic iron dissolution reaction in the corrosion process, can be transported away [37]. This transport process influences the ferrous ion concentration at the electrode and thus has a direct impact on the electrochemistry of the system. As a consequence of this electrochemical effect, denser media restrict the corrosion process more than comparatively porous systems. In summary, it is the interplay of the concrete pore structure and the exposure moisture condition, which governs the kinetics of the electrochemical iron dissolution in carbonated concrete.

It might be worth mentioning that these two fundamental influencing factors (pore structure and moisture condition) influence the electrical resistivity of the concrete. The denser the pore structure and the drier the concrete, the higher becomes the electrical resistivity. Thus, an inverse relation between the electrical resistivity and the instantaneous corrosion rate can generally be found. This relationship, however, is not a causal relationship.

Finally, the corrosion rate may be influenced by the chemical composition of the electrolyte. A number of species are known to affect the corrosion kinetics, including carbonate, bicarbonate, nitrate, nitrite, sulfate, and sulfide ions [35, 42, $51,52]$. Studies quantifying the effect of the electrolyte chemistry on the corrosion rate are, however, limited.

\subsubsection{Conditions in structures governing the corrosion rate}

Under site conditions, the internal concrete temperature follows the air temperature very closely, whereas the internal $\mathrm{RH}$ changes more slowly upon external $\mathrm{RH}$ variations. This pattern is interrupted by contact with liquid water (rain or condensation), which - through capillary suction - can lead to a fast increase of the moisture content in the concrete, at least in the zones near the surface. For the corrosion process, however, it is the moisture and temperature state at the depth of the rebar that matter.

Daily and seasonal fluctuations of the local weather are well known to lead to a dynamic behavior of the resulting corrosion rate over time [23, 53-56]. An example is shown in Fig. 8, where the instantaneous corrosion rates measured in the Finnish façades (at very shallow cover depths) were of the order of $30 \mu \mathrm{m} / \mathrm{y}$ during rain events, and dropped to below 1 $\mu \mathrm{m} / \mathrm{y}$ during the dry periods. In situations with more realistic cover depths, the internal moisture state may likely vary less. Assuming that during the wet periods the internal concrete $\mathrm{RH}$ at the steel surface approaches values around $95-100 \%$ $\mathrm{RH}$, according to Fig. 7, the instantaneous corrosion rate may be around $10 \mu \mathrm{m} / \mathrm{y}$. If, at very high moisture exposure, capillary saturation can be reached at the rebar depth, the instantaneous corrosion rate may be above $10 \mu \mathrm{m} / \mathrm{y}$, and even, but only in extreme cases, assume values of the order of $100 \mu \mathrm{m} / \mathrm{y}$. Note, however, that this can only be achieved in cases of shallow cover depth and/or coarse pore structure of the carbonated concrete cover, in combination with severe exposure conditions. This reasoning is in agreement with the practical observations reported in section 3 , where relevant corrosion damage was only found in situations of low cover depths and pronounced wetting exposure.
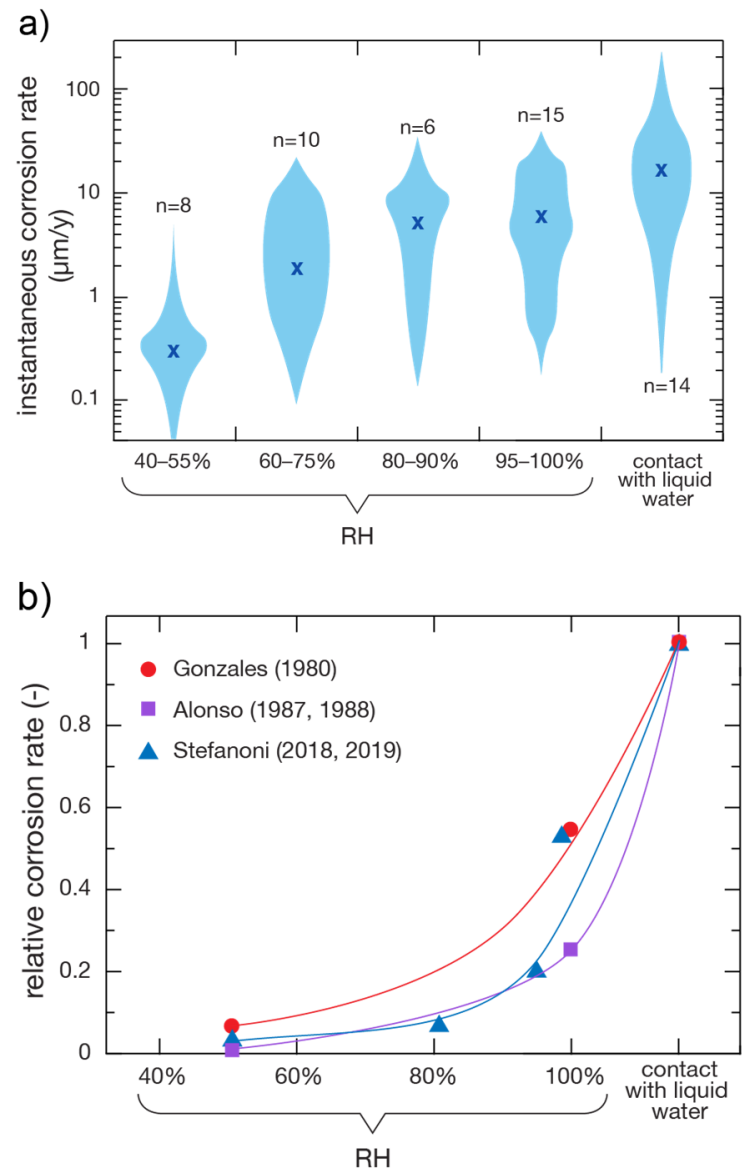

Figure 7. a) Distribution of literature values for the instantaneous corrosion rate in carbonated concrete as a function of moisture exposure condition (adopted from the literature review by Stefanoni et al. [47] that is based on more than 20 publications, and including more recent data from $[46,48-50]$. The width of the blue areas indicates the frequency of occurrence of the different values in the reviewed literature; the crosses are estimated mean values; $n$ is the number of studies. b) Data from studies reporting instantaneous corrosion rates for different moisture states (all corrosion rates were normalized with the max rate reported in "contact with liquid water"). 

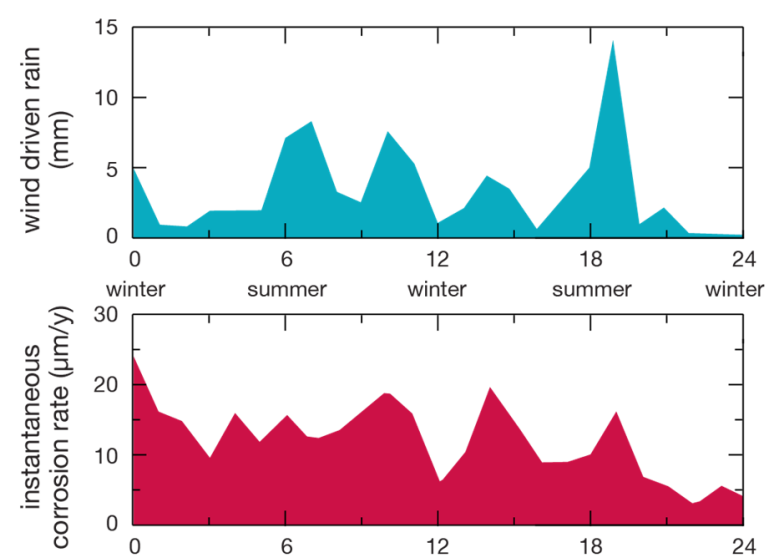

Figure 8. Data from monitoring of a structure (balcony) in Finland over two years, illustrating the correlation between wind driven rain and instantaneous corrosion rates typical for XC4 exposure conditions (corrosion rate sensors at depths 5-15 mm). Data from [23].

It is also worth mentioning that the conditions most favorable for carbonation are at considerably lower $\mathrm{RH}$ than the values needed to promote relevant corrosion. Thus, exposure conditions that combine dry periods (to favor carbonation) with wet periods (to promote active corrosion in the carbonated concrete) are needed to lead to significant corrosion attack (exposure class XC4, Table 1). This alternating exposure, however, means that the corrosion rates of the order of $10 \mu \mathrm{m} / \mathrm{y}$, expected at shallow cover depths, only occur during a fraction of the service life of a structure (wet periods), and thus, the average rate of loss of steel (integrated over the dry and wet periods) for XC4 exposure will be considerably lower.

Apart from the exposure climate, another factor that may play a role in concrete structures is the possible influence of macro-cell formation. It is well known that the pronounced cathode/anode area ratio (C/A) in chloride-induced corrosion can significantly enhance the corrosion process through galvanic corrosion $[57,58]$. Concerning the effect of macrocells in carbonation-induced corrosion, fewer studies are available. Figure 9 summarizes the results from three laboratory studies $[48,49,53]$. These studies indicate that macro-cell formation can raise the corrosion rate, generally by 50 to $250 \%$ for cathode/anode ratios around 1 . The impact increases with increasing C/A ratio. It should be noted, however, that these laboratory studies were carried out at relatively high moisture conditions and with cathode-anode distances of only a few centimeters. Caution should thus be exercised when applying these findings to practical conditions, where these two parameters may differ. The macro-cell contribution is strongly influenced by the ohmic cell resistance of the system. This ohmic resistance is governed by the C-A distance and the electrical resistivity of the concrete between $C$ and A. Short C-A distances may in practice occur, for instance in the situation where the first layer of reinforcing steel is in carbonated concrete (anode) and the second layer is still in uncarbonated concrete (cathode). However, such a condition would only exist for a limited time during the service life of a structure. On the longterm it is expected that C-A distances are comparatively large in structural members of practical dimensions. Additionally, the electrical resistivity of the concrete in practice may be higher than under the conditions in the studies shown in Fig. 9. Both these factors tend to reduce the macro-cell action. Nevertheless, the available results suggest that the corrosion rates may be enhanced through macro-cell formation at most by a factor of 2-3. Thus, macro-cell formation is possible, but expected to be of minor importance compared to the effect of moisture.

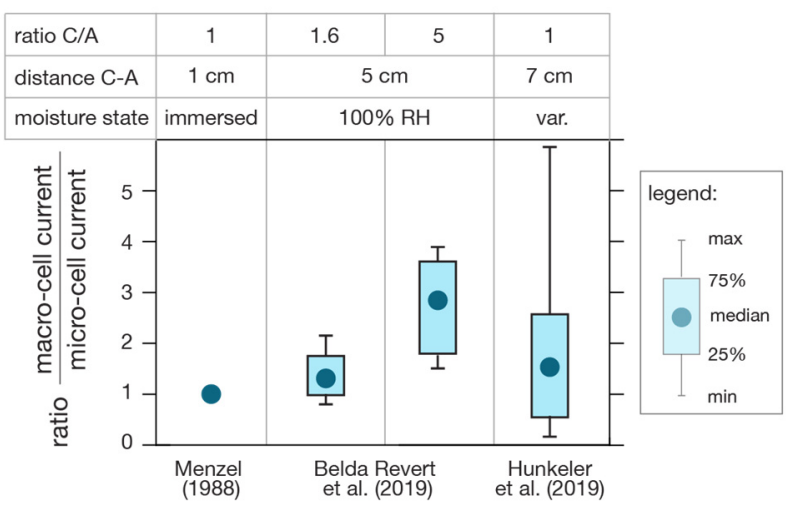

Figure 9. Contribution of macro-cell formation to the instantaneous corrosion rate in carbonated concrete, expressed as ratio of macrocell current / micro-cell current. Data from laboratory studies. Macrocell currents were measured as the galvanic current between anodic steel (in carbonated concrete) and cathodic steel (in alkaline concrete). Micro-cell currents of the steel in carbonated concrete were measured with electrochemical techniques in $[48,49]$ and estimated through gravimetric measurements in [53]. C = cathode, $A$ $=$ anode.

\subsection{Damage at the structural level}

As became apparent from the review of practical experience and fundamental mechanisms, the corrosion rates in carbonated concrete are generally negligibly low, except for periods of elevated concrete moisture conditions. Over time, however, corrosion products may accumulate and cause concrete cracking and spalling. This is because the precipitation of corrosion products within the pore system of the concrete may, under some conditions, generate crystallization pressure and lead to macroscopic expansive stresses. Various researches proposed models to predict the concrete surface cracking due to reinforcing steel corrosion in carbonated concrete. A review and critical analysis of such models can be found in [59], where it was concluded that there exists still no model that can reliably predict corrosioninduced concrete cracking. This finding can be traced back to the complexity of corrosion-induced concrete cracking and the numerous influencing factors potentially playing a role.

Due to this lack of quantitative models, a pragmatic approach has generally been used, namely that of a simple "threshold of corrosion penetration that leads to concrete cover cracking" ( $\left.p_{\text {crit }}\right)$. This critical corrosion attack is expressed in terms of accumulated loss of steel. Although the numbers given in the literature are of generally dubious theoretical origin, $p_{\text {crit }}$ appears to be around 20-100 $\mu \mathrm{m}$ [12, 41, 60-62]. Hunkeler et al. [63], based on inspections of structures and on 
laboratory data, concluded that $p_{\text {crit }}$ is not a constant, but depends on a number of influencing factors. Similar conclusions were also drawn in the extensive work carried out by Fischer [64] and Bohner [65]. Summarizing these three reports, it was concluded that the concrete cover depth, the rebar diameter, the corrosion rate, and properties of the cementitious matrix surrounding the rebar (sometimes referred to as "porous zone" accommodating the precipitating corrosion products) are the most dominant factors. Additionally, mechanical properties of the concrete may play a role (as e.g. reflected by the approach proposed in Duracrete 1998).

Figure 10 illustrates the relative importance of the different influencing factors on the basis of a calculation example by Bohner [65]. According to this example, the by far most important parameter is the corrosion rate, followed by the cover depth. Supporting evidence for the dominant role of the corrosion rate can also be found in $[13,64]$. The slower the corrosion rate, the more time is available for corrosion products to diffuse away from the rebar and precipitate at more distant locations. This mechanism also means that accelerated laboratory testing tends to lead to concrete cracking at lower $p_{\text {crit }}$ compared to generally slower corrosion processes under site conditions [12, 13].

An investigation of carbonation-induced cracking of concrete cover in concrete samples exposed to natural South African environments [66] indicated that concretes with blended cements take more time to cracking compared to plain Portland cement concrete, especially at larger cover depths. However, this cracking was connected to a significantly higher $p_{\text {crit. }}$ This was explained with a generally coarser pore structure and increased microcracking in carbonated blended cement concretes, compared to Portland cement concrete, which facilitates the uptake of corrosion products without damaging the concrete. The study also revealed the general trends that the time required for cover cracking to occur in carbonated concrete increases with a decrease in concrete quality (i.e. increase in $\mathrm{w} / \mathrm{b}$ ratio) and an increase in cover depth.

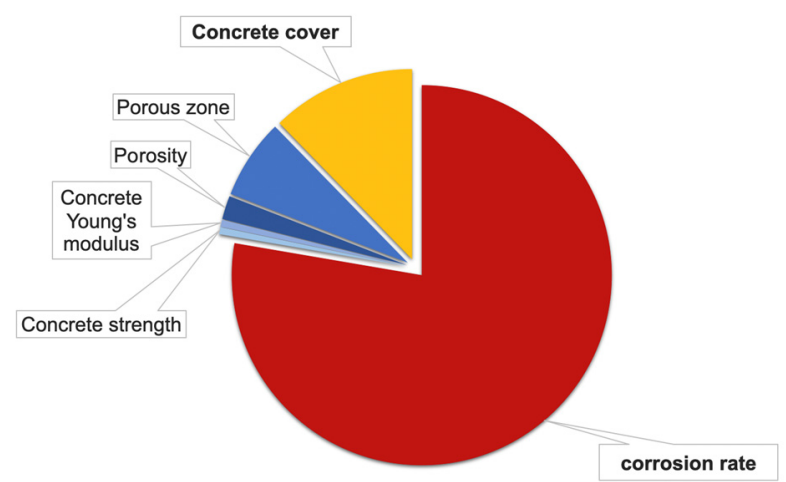

Figure 10. Relative importance of different influencing factors for the concrete cover cracking due to carbonation-induced corrosion, calculation example for a reinforced concrete column according to [65].

\section{Implications and research needs \\ 5.1 Summary of relevant processes}

From this review of practical experience and scientific understanding it can be concluded that carbonation alone is not a cause for reinforcing steel corrosion. Other factors play important roles in triggering and promoting active corrosion and in generating damage at the structural level. Hence, the focus in research should shift from studying carbonation to studying corrosion of steel in carbonated concrete (Fig. 1).

Figure 11 summarizes the corresponding processes. The most dominant influencing factors are 1) the time-dependent exposure climate (rain, ambient $\mathrm{RH}$, temperature), 2) the concrete cover depth, and 3) the microstructure of the carbonated concrete. These parameters play a crucial role in the temporospatial moisture distribution around the rebar. Furthermore, the pore structure of the carbonated concrete directly influences the instantaneous corrosion rate, and the concrete cover depth is an important parameter in controlling the damage at structural level, since higher cover depths mechanically delay cracking and spalling.

These aspects have implications for research related to the design of durable new materials and structures, inspection and condition assessment as well as prevention and repair of existing structures, as discussed in the following sections.

\subsection{Design of new materials and structures 5.2.1 Need for a new conceptual approach to service life design}

Ensuring the durability of new structures is an important challenge, because structures are increasingly being built with emerging construction technologies and modern cement types, that is, in the absence of long-term experience about the durability performance under field conditions [67, 68]. The current approach in ensuring the durability of new structures in carbonation exposure conditions essentially consists in 1) designing for the time needed for the carbonation front to reach the rebar depth (based on laboratory tests for "carbonation resistance" as a material property), and 2) possibly taking into account the corrosion propagation stage, largely based on empirical approaches.

For concretes made from low-emission binders it is generally more difficult to ensure that the carbonation front does not reach the reinforcing steel within the design service life - or at least not without largely eliminating their environmental benefits, namely by using low $\mathrm{w} / \mathrm{b}$ ratios or high cover depths. Therefore, it is important to take the corrosion propagation stage explicitly into account in the service life design and to reliably keep the corrosion process in check. 


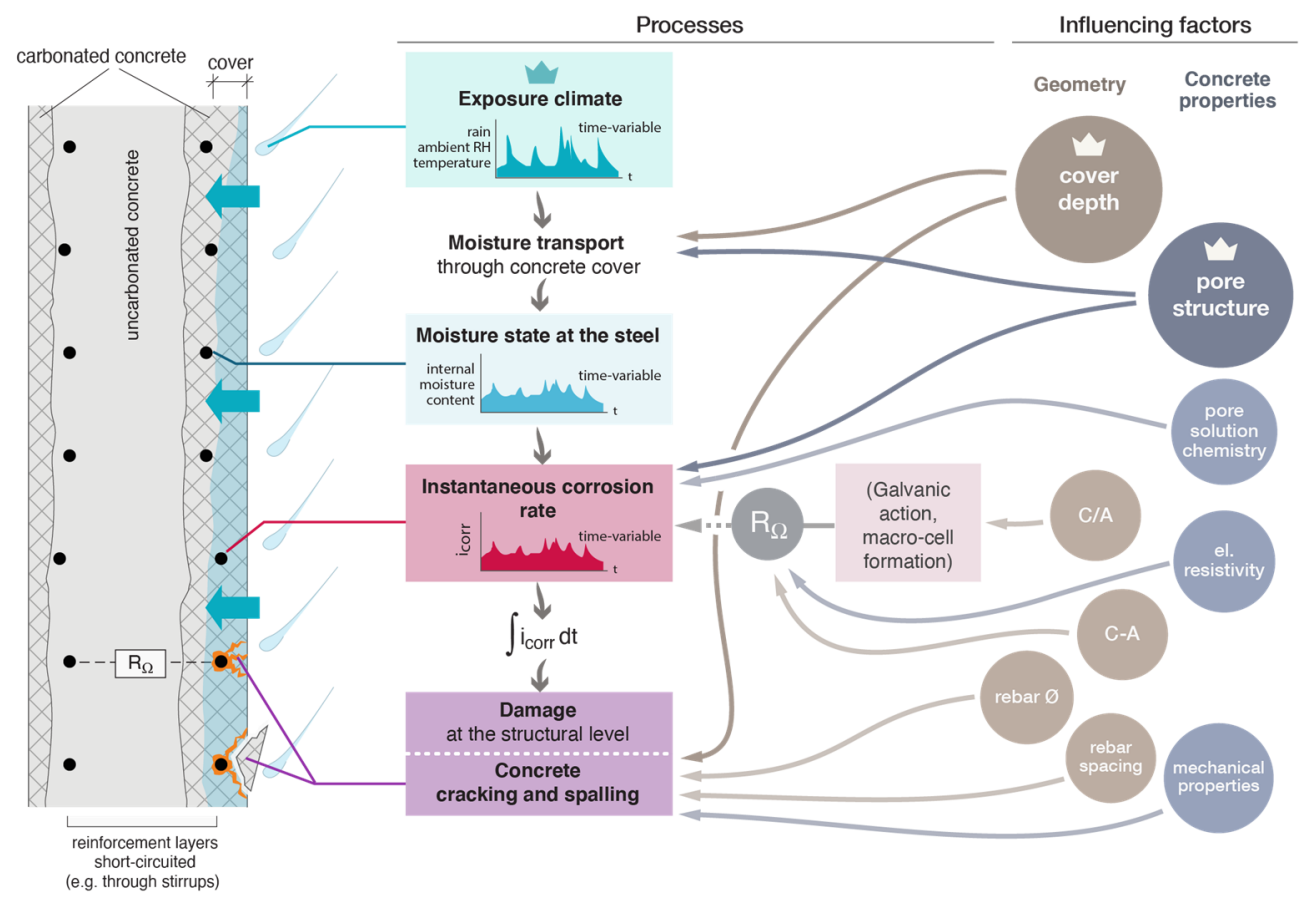

Figure 11. Summary of processes leading to corrosion-related damage in carbonated reinforced concrete (in the absence of chlorides) and their influencing factors. $\mathrm{C} / \mathrm{A}=$ cathode / anode area ratio; $\mathrm{C}-\mathrm{A}=$ cathode - anode distance; $R_{\Omega}=$ ohmic concrete resistance in the galvanic element. The crown symbol highlights the most important influencing factors.

As moisture plays a fundamental role in the corrosion propagation stage, future concepts may benefit from explicitly considering this parameter. Essentially, this would mean a paradigm change in durability design, namely that the current conceptual understanding of the concrete cover as primarily a protection against carbonation would be expanded towards or replaced with a conceptual understanding of the concrete cover as a protective barrier against ingress of moisture into carbonated concrete. This new concept ultimately would mean to design the (carbonated) concrete cover as a protection against moisture ingress. Without this change - that is by keeping the focus on "avoidance of carbonation" as the primary line of defense against carbonation-induced corrosion degradation - it will be challenging to reduce the environmental impact of $\mathrm{RC}$ structures constructed with low-emission binder types.

\subsubsection{Assessing the durability performance of different binders}

The circumstance that a reduced $\mathrm{pH}$ alone is not sufficient to lead to significant steel corrosion in concrete seriously challenges the established approach of assessing the durability performance based on carbonation testing and modeling. Instead, the roles that changes in the microstructure and in the pore solution chemistry upon carbonation as well as the moisture content at the reinforcement play in the corrosion process need to be considered.

Alterations in microstructure are both due to phase changes and carbonation shrinkage-induced microcracking, which impacts the transport properties and penetrability of the concrete [69]. In Portland cement concrete, carbonation of Portlandite results in precipitation of $\mathrm{CaCO}_{3}$ in the pore system, which results in clogging capillary pores and produces a denser matrix [50, 70]. In contrast, concretes with blended cements contain significantly lower amounts of Portlandite, which generally results in coarsening of their pore structure during carbonation [50, 71-73]. In addition, blended cements often contain a higher amount of AFt and AFm phases exhibiting substantial volume decrease at carbonation [74]. Several researchers [73, 75-80] measured a significant increase in transport properties due to carbonation in blended cement pastes, such as diffusion and permeation coefficients. Auroy et al. [77] studied the impact of carbonation on unsaturated water transport in concrete. In their results, pore clogging prevailed over micro-cracking in Portland cement concretes, causing reduced permeability. The opposite was observed for concretes made with blended cements containing slag, fly ash or silica fume, which was assigned to microcracking related to shrinkage caused by C-S$\mathrm{H}$ decalcification. Nevertheless, it should be borne in mind that looking at changes in pore structure and transport properties upon carbonation with respect to the state before carbonation alone is not sufficient to assess different binders in terms of their durability performance. Although concretes made from blended cements may show a coarsening of their pore structure upon carbonation, they may still be denser than carbonated Portland cement concretes.

Apart from the pore structure and the moisture state, the chemical composition of the pore solution may also influence reinforcement corrosion. Data on the pore solution composition of carbonated systems is relatively scarce in the 
literature. It is known that carbonation results in a decrease in the hydroxyl concentration, variations in the carbon content, a reduction of the carbonate-to-bicarbonate ratio, and a release of detrimental ions such as chlorides and sulphates $[33,34]$. The prevalence of these mechanisms with regard to various binder types requires further research.

According to $[47,50,66]$ corrosion rates of steel in carbonated concrete increase with an increasing level of cement clinker replacement. Nevertheless, it remains unclear if this increase in corrosion rate is mainly due to the differences in pore structure or differences in pore solution chemistry of blended systems compared to Portland cement, and to what extent this affects the durability performance. Otieno et al. [66], for instance, found that despite the higher corrosion rates, concretes with blended cements consistently showed a longer time to corrosion-induced cover cracking in combination with greater loss in steel cross sections. Possible reasons for these observations relate to the influence of binder type on the microstructure of carbonated concrete.

\subsubsection{Research needs}

Investigating the influences of carbonation-induced changes in the pore structure and pore solution chemistry of concrete containing blended cements on reinforcement corrosion should be a research priority. There is clearly a need for further investigation to fully understand the interaction and consequences of the various phenomena described in literature. In this context, the concrete properties at the steelconcrete interface are of major importance. RILEM TC 262-SCI is currently reviewing methods to characterize the steelconcrete interface, which is expected to give more specific guidance for future related research.

Additionally, considering the findings of our review (summarized in Fig. 11), scientific advances are needed to quantitatively describe the phenomena related to moisture transport and retention in the carbonated cementitious matrix. Without doubt, progress was made in moisture transport modeling in concrete [81-84]. Nevertheless, there is a need to further develop these models, such as towards including moisture transport upon contact of the concrete surface with liquid water, and in particular to validate them against experiments performed with carbonated concrete. Finally, there are very few studies coupling modeling of moisture and corrosion in concrete. In this regard, particular research opportunities are seen in integrating the fundamental understanding about the mechanism of corrosion in carbonated concrete (section 4.2.1) and to consider the transport and precipitation of corrosion products in concrete with the help of reactive transport models.

\subsection{Inspection and condition assessment of existing structures

5.3.1 The need to consider corrosion
propagation for reliable durability
prognoses

The objective of condition assessment (compare section 3 for a brief review of common methods used) is to evaluate the extent of current deterioration and to make a prognosis. A situation encountered in practice is that the carbonation depth has closely approached, reached or exceeded the cover depth, but that the steel does not yet show significant corrosion damage. To assess the future risk of corrosion in these cases (prognosis), it is crucial to consider additional factors such as the possible presence of chlorides and, in particular, the moisture conditions. The importance of these aspects in condition assessment is clearly apparent from this review and has already been stated earlier in standards [16].

\subsubsection{Moisture conditions at the rebar depth}

However, although many methods to determine moisture in concrete exist [85], the moisture condition at the rebar level is difficult to quantify, especially with non-destructive methods and methods suitable to be adopted in engineering practice. Useful indicators may be the cover depth as well as parameters related to the porosity of the cover concrete, as with increasing cover depth and with denser porosity, the moisture condition at the rebar level is less affected by the weather conditions. Estimates for the moisture state of the concrete may be obtained from electrical concrete resistivity measurements, e.g. by means of surface measurements with Wenner probes [86] or with embedded sensors [87]. A major advantage of these measurements is that they are fast and non-destructive. However, the interpretation of on-site surface resistivity measurements is not straightforward and requires expert knowledge [86], because, for instance, the concrete resistivity is not only dependent on the moisture content, but also on other factors, including the concrete pore structure and the pore solution chemistry $(\mathrm{pH})$. Additionally, the concrete resistivity in structures is generally spatially variable, which can severely complicate the interpretation of surface resistivity measurements [88].

Thus, with the established (non-destructive) methods, it is very difficult to quantify the moisture state at the rebar depth during the inspection of structures. In view of the importance of the moisture state for the development of corrosion damage in carbonated structures, we see particular opportunities for further research to deliver reliable methods to quantify the moisture condition at the rebar depth. Promising approaches may be tomographic methods, e.g. electrical resistance tomography $[89,90]$.

\subsubsection{On-site corrosion rate measurements}

An alternative to quantifying the moisture state is the direct determination of the corrosion rate. Given the generally low rates of corrosion (Fig. 7), mass loss measurements are often not feasible. Electrochemical methods [18], on the other hand, are a powerful tool to quantify the instantaneous corrosion rates on-site. It should be mentioned, however, that electrochemical corrosion rate measurements deliver instantaneous corrosion rates. Having in mind the dramatic fluctuations over time (Fig. 8), such measurements should thus be interpreted with caution, as a single measurement, taken at a certain temperature and moisture condition, cannot represent the time-dependent variation of the corrosion activity and is limited in terms of extrapolating and making predictions. Suggestions how to overcome this were 
made in $[18,91]$. For instance, frequent measurements of the corrosion rate over a representative period can be made to obtain reliable average corrosion rates for the estimation of the remaining service life. An alternative to frequent corrosion rate measurements on-site is the use of sensors and monitoring systems; for more details it is referred to [92]. Although techniques are available to measure and monitor the corrosion rate in carbonated concrete, the use of these techniques in assessing the condition of carbonated concrete structures is not common in many countries. We are convinced that including such techniques more in inspections can improve the diagnosis and prognosis of the condition of carbonated structures and thus play valuable roles in supporting decisions for predictive maintenance.

\subsection{Prevention and repair}

\subsubsection{Effect of surface treatments on carbonation}

The carbonation of concrete can generally be reduced by most surface treatments, the most commonly applied treatments including barrier coatings based on acrylics, polyurethane or epoxy [93, 94]. These barrier coatings are prone to deterioration, often require substantial maintenance, and they have the limitation of changing the aesthetic appearance of the concrete surface. Another type of surface treatment which does not affect the appearance of the concrete relates to hydrophobic impregnation. With regards to carbonation, several studies in the literature indicate that a hydrophobic surface treatment is ineffective in significantly reducing carbonation rates [95] or may even accelerate carbonation, which was assigned to the circumstance that the hydrophobic treatment depresses the concrete moisture content, thus facilitating carbonation [96]. In contrast, other studies reported a positive effect of hydrophobic surface treatment on carbonation progression $[97,98]$, while Xu et al. [99] related the potential effect of a silane treatment to the initial porosity of the concrete, suggesting that hydrophobic treatment may be more effective in concrete with a dense pore structure.

\subsubsection{Effect of surface treatments on corrosion in carbonated concrete}

While the above studies [93-99] concern the effect of hydrophobic treatments on the carbonation process, the literature is scarce regarding the effect on reinforcement corrosion in carbonated concrete. Even in cases where hydrophobic treatment reduces the saturation of the concrete pore structure to a degree that facilitates ongoing carbonation, the reduced saturation may simultaneously assist with reducing reinforcement corrosion rates significantly. This effect of surface treatments was shown in [100]. Four different coatings were studied by means of monitoring the corrosion rate with sensors embedded at cover depths $<15 \mathrm{~mm}$ in carbonated concrete exposed as façades in Finland. The studied coatings were silicate paint (permeable treatment for a reference), silicon resin paint, hydrophobic primer and acrylic paint, and polymer modified finishing mortar and acrylic paint. The average yearly corrosion attack was $7 \mu \mathrm{m}, 1.5 \mu \mathrm{m}, 1.4 \mu \mathrm{m}$ and $1.7 \mu \mathrm{m}$, respectively.

Another preventive or repair method also based on the use of hydrophobic agents consists in the new generation of migrating corrosion inhibitors that are designed to penetrate from the exterior of the element. Some of these materials consist of a mixture between a hydrophobic agent and a corrosion inhibitor. This type of inhibitors may either act before corrosion is active or stop an already active corrosion process. The immediate effect is an increase in resistivity due to the drying provoked, in combination with the corrosion inhibiting action on the steel surface. The efficacy of such multifunctional inhibitors was discussed in [101]. Since the penetration depth of migrating corrosion inhibitors is crucial, further investigations are needed. However, in particular for shallow cover depth, this approach may be an interesting prevention and repair approach.

\subsubsection{Research needs}

The use of surface treatments, in particular hydrophobic treatments, requires systematic future research in order to evaluate if and how surface treatments can extend the service life of concrete structures in carbonation exposure conditions, taking into account both corrosion initiation and propagation phases.

\section{Conclusions}

This review considered both practical experience and scientific state-of-the-art understanding on reinforcing steel corrosion in carbonated concrete. The following major conclusions are drawn:

1. The view generally held in concrete and cement research, namely that carbonation of the concrete leads to reinforcing steel corrosion, is too simplistic. A review of almost 1000 cases of inspected concrete structures in which the carbonation front had reached the reinforcement revealed that in many cases carbonation did not lead to noticeable corrosion or related damage.

2. The most important parameter controlling the corrosion rate is the moisture state at the steel-concrete interface. If capillary saturation can be reached, the instantaneous corrosion rate can temporarily peak in the range 10 $50 \mu \mathrm{m} / \mathrm{y}$.

3. The influencing factors controlling whether or not carbonation leads to corrosion damage at the structural level are the time-variable moisture exposure conditions, the cover depth, and the microstructure and pore solution chemistry of the carbonated matrix at the steelconcrete interface.

4. The circumstance that a reduced $\mathrm{pH}$ alone is not sufficient to lead to significant steel corrosion in concrete seriously challenges the established approach of assessing the long-term durability performance based on carbonation testing and modeling. At the same time, this circumstance offers great opportunities for reducing the environmental impact of concrete structures with low-emission binders.

5. Particular opportunities are seen in facilitating a paradigm change from the current "avoidance of carbonation 
approach" to a mechanism-based "avoidance of corrosion damage approach". This means a new conceptual mindset that embraces the role of the concrete cover as a protective barrier against moisture ingress and as mechanical resistance designed to withstand the expansive pressures arising from corrosion, thus delaying and limiting concrete cracking.

6. To realize these opportunities, the focus in research should shift from studying carbonation to studying corrosion of steel in carbonated concrete, especially for blended cements. The fundamental understanding and quantification of the influences listed in conclusions no. 2 and 3 above should be research priorities.

\section{Acknowledgements}

This paper resulted from work carried out by working group 5 "effect of carbonation on corrosion of concrete with SCMs" of RILEM TC 281-CCC "Carbonation of concrete with supplementary cementitious materials". The Swiss Society for Corrosion Protection and the material testing institute IMP Bautest AG are acknowledged for providing data related to practical experience from Switzerland.

\section{CRediT author statement}

Ueli Angst: Conceptualization, Formal analysis, Investigation, Writing - Original Draft, Visualization, Supervision. Fabrizio Moro: Conceptualization, Formal analysis, Investigation, Writing - Review \& Editing. Mette Geiker: Conceptualization, Investigation, Writing - Original Draft. Sylvia Kessler: Conceptualization, Writing - Original Draft. Hans Beushausen: Investigation, Writing - Original Draft. Carmen Andrade: Investigation, Writing - Review \& Editing. Jukka Lahdensivu: Formal analysis, Investigation, Writing - Review \& Editing. Arto Köliö: Formal analysis, Investigation. Kei-ichi Imamoto: Conceptualization, Writing - Review \& Editing. Stefanie von Greve-Dierfeld: Writing - Review \& Editing. Marijana Serdar: Writing - Review \& Editing.

\section{References}

[1] S. Uchida, M. Hamada, Durability test of steel and concrete (in Japanese). J Archit Build Sci (1928) 516:1287-1303

[2] M. Hamada, Neutralization (carbonation) of concrete and corrosion of reinforcing steel. Proc. 5th Int. Symp. on Cement Chemistry, The Cement Association of Japan, Tokyo, 1968, 343-369.

[3] I. Galan, C. Andrade, P. Mora, M. A. Sanjuan, Sequestration of $\mathrm{CO} 2$ by Concrete Carbonation. Environ Sci Technol (2010) 44:3181-3186 https://doi.org/10.1021/es903581d

[4] B. J.Zhan, C. S. Poon, C. J. Shi, CO2 curing for improving the properties of concrete blocks containing recycled aggregates. Cem Concr Comp (2013) 42:1-8. https://doi.org/10.1016/i.cemconcomp.2013.04.013

[5] P. Utgenannt, Influence of carbonation on the scaling resistance of OPC concrete. Proc. int. RILEM Workshop on Frost Damage in Concrete, D. J. JANSSEN, M. J. SETZER and M. B. SNYDER (Eds.), 2002, 102-113.

[6] S. Adu-Amankwah, M. Zajac, J. Skocek, M. Ben Haha, L. Black, Relationship between cement composition and the freeze-thaw resistance of concretes. Adv Cem Res (2018) 30(8):387-397. https://doi.org/10.1680/jadcr.17.00138

[7] European Standard EN 1992-1-1 "Eurocode 2: Design of concrete structures - Part 1-1: General rules and rules for buildings", European Committee for Standardization, 2004.
[8] European Standard EN 206-1 "Concrete - Part 1: Specification, performance, production and conformity", European Committee for Standardization, 2000.

[9] K. Tuutti, Corrosion of steel in concrete, Swedish Cement and Concrete Research Institute, 1982.

[10] J. G. Cabrera, Deterioration of concrete due to reinforcement steel corrosion. Cem Concr Comp (1996) 18(1):47-59. https://doi.org/10.1016/0958-9465(95)00043-7

[11] A. A. Almusallam, A. S. AlGahtani, A. R. Aziz, Rasheeduzzafar, Effect of reinforcement corrosion on bond strength. Constr Build Mater (1996) 10(2):123-129. https://doi.org/10.1016/0950-0618(95)00077-1

[12] C. Alonso, C. Andrade, J. Rodriguez, J. M. Diez, Factors controlling cracking of concrete affected by reinforcement corrosion. Mater Struct (1998) 31(211):435-441. https://doi.org/10.1007/BF02480466

[13] M. Stefanoni, Z. Zhang, U. Angst, B. Elsener, The kinetic competition between transport and oxidation of ferrous ions governs precipitation of corrosion products in carbonated concrete. RILEM Tech Lett (2018) 3:8-16. https://doi.org/10.21809/rilemtechlett.2018.57

[14] J. Nepal, H. P. Chen, Evaluation of residual strength of corrosion damaged reinforced concrete structures. Life-Cycle of Structural Systems: Design, Assessment, Maintenance and Management (2015):443-450. https://doi.org/10.1201/b17618-63

[15] JSCE Guidelines for Concrete, No. 17. "Standard specification for concrete structures - maintenance". ISBN 978-4-8106-0754-3, JSCE Japanese Society of Civil Engineers, 2007.

[16] Standard SIA 269/2:2011. Existing structures - concrete structures, SIA - Swiss Society of Engineers and Architects, 2011.

[17] European Standard EN 1504-9 "Products and systems for the protection and repair of concrete structures - Definitions, requirements, quality control and evaluation of conformity - Part 9: General principles for the use of products and systems", European Committee for Standardization, 2008.

[18] C. Andrade, C. Alonso, J. Gulikers, R. Polder, R. Cigna, $\emptyset$. Vennesland, M. Salta, A. Raharinaivo, B. Elsener, Recommendation of RILEM TC 154-EMC: "Test methods for on-site corrosion rate measurement of steel reinforcement in concrete by means of the polarization resistance method". Mater Struct (2004) 37(273):623-643. https://doi.org/10.1617/13952

[19] J. Rodriguez, L. M. Ortega, A. M. Garcia, L. Johansson, K. Petterson, On site corrosion arte measurements in concrete structures using a device developed under the EUREKA project EU-401. Proc. Conference "Concrete Across borders" June 1994, Odense, Denmark, Palladian Publications Ltd, 1995, 215-226.

[20] N. Rebolledo, J. E.Torres, J. Sánchez, Corrosion of Carbonated Structures. Real Cases of Structures in Spain. Proc. RILEM Spring convention, Guimarães, Portugal, 2020

[21] A. B. Revert, Personal communication, Norconsult AS, Oslo, Norway, 2019.

[22] J. Mattila, M. Pentti, Residual service-life of concrete façade structures with reinforcement in carbonated concrete in Nordic climate. in: Tailor made concrete structures, London, UK, Taylor \& Francis Group, 2008, 75-79.

[23] A. Köliö, T. A. Pakkala, H. Hohti, A. Laukkarinen, J. Lahdensivu, J. Mattila, M. Pentti, The corrosion rate in reinforced concrete facades exposed to outdoor environment. Mater Struct (2017) 50(1) https://doi.org/10.1617/s11527-016-0920-7

[24] W. J. Chitty, P. Dillmann, V. L'Hostis, C. Lombard, Long-term corrosion resistance of metallic reinforcements in concrete - a study of corrosion mechanisms based on archaeological artefacts. Corros Sci (2005) 47(6):1555-1581. https://doi.org/10.1016/j.corsci.2004.07.032

[25] DuraCrete Final Technical Report, "DuraCrete - Probabilistic performance based durability design of concrete structures". The European Union - Brite EuRam III, 2000.

[26] K.-i. Imamoto, M. Kanematsu, C. Kiyohara, H. Hamasaki, T. Kinose, K. Teranishi, T. Noguchi, Field survey on rebar corrosion of carbonated existing concrete buildings in Japan. Proc. Int. Conf. on Sustainable Materials, Systems and Structures (SMSS2019), Rovinj, Croatia, A. Baričević, M. J. Rukavina, D. Damjanović and M. Guadagnini (Eds.), RILEM Publications SARL, 2019, 2-9.

[27] J. Lahdensivu, Durability properties and actual deterioration of Finnish concrete facades and balconies. Publication 1028. Tampere University of Technology, Tampere, Finland, 2012.

[28] K. Su, K.-i. Imamoto, T. Noguchi, M. Kanematsu, H. Hamasaki, K. Teranishi, C. Kiyohara, M. Yamada, Post peak behavior of carbonated concrete structure - a case study of the former shime mining office vertical derrick in Japan. Proc. XV Int. Conf. on Durability of Building 
Materials and Components, Barcelona, Spain, C. Serrat, J. R. Casas and V. Gibert (Eds.), 2020,

[29] L. Bertolini, B. Elsener, P. Pedeferri, E. Redaelli, R. Polder, Corrosion of Steel in Concrete: Prevention, Diagnosis, Repair (2nd Edition). WILEY VCH, Weinheim, 2013. https://doi.org/10.1002/9783527651696

[30] Corrosion of steel in concrete, report of RILEM TC 60-CSC. P. Schiessl (Ed.) Chapman and Hall, London, UK, 1988.

[31] D. A. Hausmann, Steel corrosion in concrete. How does it occur? Mater. Protection (1967) 6:19-23

[32] V. K. Gouda, Corrosion and corrosion inhibition of reinforcing steel. I. Immersed in alkaline solutions. Br Corros J (1970) 5:198-203. https://doi.org/10.1179/000705970798324450

[33] Y. S. Femenias, U. Angst, F. Moro, B. Elsener, Development of a novel methodology to assess the corrosion threshold in concrete based on simultaneous monitoring of $\mathrm{pH}$ and free chloride concentration. Sensors (2018) 18:3101. https://doi.org/10.3390/s18093101

[34] K. De Weerdt, G. Plusquellec, A. B. Revert, M. R. Geiker, B. Lothenbach, Effect of carbonation on the pore solution of mortar. Cem Concr Res (2019) 118:38-56. https://doi.org/10.1016/i.cemconres.2019.02.004

[35] B. Huet, V. L'Hostis, L. Tricheux, H. Idrissi, Influence of alkali, silicate, and sulfate content of carbonated concrete pore solution on mild steel corrosion behavior. Mater Corros (2010) 61(2):111-124. https://doi.org/10.1002/maco.200905244

[36] L. J. Parrott, A Study of Carbonation-Induced Corrosion. Mag Concr Res (1994) 46(166):23-28. https://doi.org/10.1680/macr.1994.46.166.23

[37] M. Stefanoni, U. M. Angst, B. Elsener, Kinetics of electrochemical dissolution of metals in porous media. Nat Mater (2019) 18(9):942947. https://doi.org/10.1038/s41563-019-0439-8

[38] U. M. Angst, M. R. Geiker, A. Michel, C. Gehlen, H. Wong, O. B. Isgor, B. Elsener, C. M. Hansson, R. Francois, K. Hornbostel, R. Polder, M. C. Alonso, M. Sanchez, M. J. Correia, M. Criado, A. Sagues, N. Buenfeld, The steel-concrete interface. Mater Struct (2017) 50(2):143. https://doi.org/10.1617/s11527-017-1010-1

[39] U. R. Evans, The corrosion and oxidation of metals: Scientific principles and practical applications. Edward Arnold Ltd, London, 1960.

[40] A. B. Revert, K. De Weerdt, K. Hornbostel, M. R. Geiker, Carbonationinduced corrosion: Investigation of the corrosion onset. Constr Build Mater (2018) 162:847-856. https://doi.org/10.1016/i.conbuildmat.2017.12.066

[41] Köliö, M. Honkanen, J. Landensivu, M. Vippola, M. Pentti, Corrosion products of carbonation induced corrosion in existing reinforced concrete facades. Cem Concr Res (2015) 78:200-207. https://doi.org/10.1016/i.cemconres.2015.07.009

[42] J. A. Gonzalez, S. Algaba, C. Andrade, Corrosion of Reinforcing Bars in Carbonated Concrete. Br Corros J (1980) 15(3):135-139. https://doi.org/10.1179/bcj.1980.15.3.135

[43] C. Alonso, C. Andrade, J. A. González, Relation between resistivity and corrosion rate of reinforcements in carbonated mortar made with several cement types. Cem Concr Res (1988) 8:687-698. https://doi.org/10.1016/0008-8846(88)90091-9

[44] G. K. Glass, C. L. Page, N. R. Short, Factors affecting the corrosion rate of steel in carbonated mortars. Corros Sci (1991) 32(12):1283-1294. https://doi.org/10.1016/0010-938X(91)90048-T

[45] R. K. Dhir, M. R. Jones, M. J. Mccarthy, Pulverized-Fuel Ash Concrete Carbonation-Induced Reinforcement Corrosion Rates. P I Civil Eng-Str B (1992) 94(3):335-342. https://doi.org/10.1680/istbu.1992.20293.

[46] M. Stefanoni, U. M. Angst, B. Elsener, Electrochemistry and capillary condensation theory reveal the mechanism of corrosion in dense porous media. Sci Rep (2018) 8(1):7407. https://doi.org/10.1038/s41598-018-25794-x

[47] M. Stefanoni, U. Angst, B. Elsener, Corrosion rate of carbon steel in carbonated concrete - A critical review. Cem Concr Res (2018) 103:3548. https://doi.org/10.1016/j.cemconres.2017.10.007

[48] A. B. Revert, K. Hornbostel, K. De Weerdt, M. R. Geiker, Macrocell corrosion in carbonated Portland and Portland-fly ash concrete Contribution and mechanism. Cem Concr Res (2019) 116:273-283. https://doi.org/10.1016/i.cemconres.2018.12.005

[49] F. Hunkeler, S. v. Greve-Dierfeld, Karbonatisierung von Beton und Korrosionsgeschwindigkeit der Bewehrung im karbonatisierten Beton. ASTRA/VSS Report no. 696. Bundesamt für Strassen, Berne, Switzerland, 2019.
[50] M. Serdar, S. Poyet, V. L'Hostis, D. Bjegovic, Carbonation of lowalkalinity mortars: Influence on corrosion of steel and on mortar microstructure. Cem Concr Res (2017) 101:33-45. https://doi.org/10.1016/j.cemconres.2017.08.013

[51] M. Stefanoni, U. Angst, B. Elsener, Influence of Calcium Nitrate and Sodium Hydroxide on Carbonation-Induced Steel Corrosion in Concrete. Corrosion (2019) 75(7):737-744. https://doi.org/10.5006/3085

[52] F. Martinelli-Orlando, W. Shi, U. Angst, Corrosion Behavior of Carbon Steel in Alkaline, Deaerated Solutions: Influence of Carbonate lons. J Electrochem Soc (2020) 167(6). https://doi.org/10.1149/1945-7111/ab7d44

[53] K. Menzel, Karbonatisierungszellen - Ein Beitrag zur Korrosion von Stahl in karbonatisiertem Beton. Mater Corros (1988) 39:123-129. https://doi.org/10.1002/maco.19880390303

[54] C. Andrade, A. Castillo, Evolution of reinforcement corrosion due to climatic variations. Mater Corros (2003) 54(6):379-386 https://doi.org/10.1002/maco.200390087

[55] R. Weydert, Randbedingungen bei der Instandsetzung nach dem Schutzprinzip W bei Bewehrungskorrosion im karbonatisierten Beton. Heft 552, Deutscher Ausschuss für Stahlbeton, Beuth-Verlag, ISBN 3-410-65752-5., RWTH Aachen, Germany, 2005.

[56] M. Stefanoni, U. Angst, B. Elsener, The mechanism controlling corrosion of steel in carbonated cementitious materials in wetting and drying exposure. Cem Concr Compos (2020) 113:103717. https://doi.org/10.1016/j.cemconcomp.2020.103717

[57] C. Andrade, I. R. Maribona, S. Feliu, J. A. Gonzalez, The effect of macrocells between active and passive areas of steel reinforcements. Corros Sci (1992) 33(2):237-249. https://doi.org/10.1016/0010-938X(92)90148-V

[58] M. Raupach, Chloride-induced macrocell corrosion of steel in concrete-theoretical background and practical consequences. Constr. Build. Mater. (1996) 10(5):329-338. https://doi.org/10.1016/0950-0618(95)00018-6

[59] A. Jamali, U. Angst, B. Adey, B. Elsener, Modeling of corrosioninduced concrete cover cracking: A critical analysis. Const Build Mater (2013) 42:225-237. https://doi.org/10.1016/j.conbuildmat.2013.01.019

[60] A. J. M. Siemes, A. C. W. M. Vrouwenvelder, A. v. d. Beukel, Durability of buildings: a reliability analysis. Heron (1985) 30:3-48.

[61] L. J. Parrott, A review of carbonation in reinforced concrete. Cement and Concrete Association, UK, 1987.

[62] J. P. Broomfield, Corrosion of steel in concrete. Chapman \& Hall, 1997. https://doi.org/10.4324/9780203414606

[63] F. Hunkeler, B. Mühlan, H. Ungricht, Risk of spalling of concrete due to rebar corrosion. Research report ASTRA AGB 2002/015. Swiss Federal Roads Office, Berne, Switzerland, 2006.

[64] C. Fischer, Auswirkungen der Bewehrungskorrosion auf den Verbund zwischen Stahl und Beton, Technical University Stuttgart, Germany, 2012.

[65] E. Bohner, Rissbildung in Beton infolge Bewehrungskorrosion, Karlsruher Institut für Technologie (KIT), Germany, 2013.

[66] M. Otieno, J. Ikotun, Y. Ballim, Experimental investigations on the influence of cover depth and concrete quality on time to cover cracking due to carbonation-induced corrosion of steel in RC structures in an urban, inland environment. Constr Build Mater (2019) 198:172-181. https://doi.org/10.1016/j.conbuildmat.2018.11.215

[67] C. L. Page, M. M. Page, Durability of concrete and cement composites, Woodhead Publishing Ltd., 2007.

[68] U. M. Angst, Challenges and opportunities in corrosion of steel in concrete. Mater Struct (2018) 51(4). https://doi.org/10.1617/s11527-017-1131-6

[69] S. von Greve-Dierfeld, B. Lothenbach, A. Vollpracht, B. Wu, B. Huet, C. Andrade, C. Medina, C. Thiel, E. Gruyaert, H. Vanoutrive, I. F. S. d. Bosque, I. Ignjatovic, J. Elsen, J. L. Provis, K. Scrivener, K.-C. Thienel, K. Sideris, M. Zajac, N. Alderete, Ö. Cizer, P. V. d. Heede, R. D. Hooton, S. Kamali-Bernard, S. A. Bernal, Z. Zhao, Z. Shi, N. D. Belie, Understanding the Carbonation of Concrete with Supplementary Cementitious Materials - a critical review by RILEM TC 281-CCC. Mater Struct (in press).

[70] S. E. Pihlajavaara, Some results of the effect of carbonation on the porosity and pore size distribution of cement paste. Mater Struct (1968) 1(6):521-527. https://doi.org/10.1007/BF02473640

[71] B. Savija, M. Lukovic, Carbonation of cement paste: Understanding, challenges, and opportunities. Constr Build Mater (2016) 117:285301. https://doi.org/10.1016/i.conbuildmat.2016.04.138 
[72] Z. G. Shi, B. Lothenbach, M. R. Geiker, J. Kaufmann, A. Leemann, S. Ferreiro, J. Skibsted, Experimental studies and thermodynamic modeling of the carbonation of Portland cement, metakaolin and limestone mortars. Cem Concr Res (2016) 88:60-72. https://doi.org/10.1016/j.cemconres.2016.06.006

[73] Morandeau, M. Thiery, P. Dangla, Impact of accelerated carbonation on OPC cement paste blended with fly ash. Cem Concr Res (2015) 67:226-236. https://doi.org/10.1016/j.cemconres.2014.10.003

[74] H. Justnes, J. Skocek, T. A. Østnor, C. J. Engelsen, O. Skjølsvold, Microstructural changes of hydrated cement blended with fly ash upon carbonation. Cem Concr Res (2020) 137:106192. https://doi.org/10.1016/j.cemconres.2020.106192

[75] V. T. Ngala, C. L. Page, Effects of carbonation on pore structure and diffusional properties of hydrated cement pastes. Cem Concr Res (1997) 27(7):995-1007. https://doi.org/10.1016/S0008-8846(97)00102-6

[76] P. H. R. Borges, J. O. Costa, N. B. Milestone, C. J. Lynsdale, R. E. Streatfield, Carbonation of $\mathrm{CH}$ and $\mathrm{C}-\mathrm{S}-\mathrm{H}$ in composite cement pastes containing high amounts of BFS. Cem Concr Res (2010) 40(2):284292. https://doi.org/10.1016/j.cemconres.2009.10.020

[77] M. Auroy, S. Poyet, P. Le Bescop, J. M. Torrenti, T. Charpentier, M. Moskura, X. Bourbon, Impact of carbonation on unsaturated water transport properties of cement-based materials. Cem Concr Res (2015) 74:44-58. https://doi.org/10.1016/j.cemconres.2015.04.002

[78] Leemann, H. Pahlke, R. Loser, F. Winnefeld, Carbonation resistance of mortar produced with alternative cements. Mater Struct (2018) 51(5). https://doi.org/10.1617/s11527-018-1239-3

[79] Leemann, R. Loser, B. Munch, P. Lura, Steady-state 0-2 and CO2 diffusion in carbonated mortars produced with blended cements. Mater Struct (2017) 50(6). https://doi.org/10.1617/s11527-017-1118-3

[80] M. Boumaaza, P. Turcry, B. Huet, A. Ait-Mokhtar, Influence of carbonation on the microstructure and the gas diffusivity of hardened cement pastes. Constr Build Mater (2020) 253. https://doi.org/10.1016/j.conbuildmat.2020.119227

[81] O. B. Isgor, A. G. Razaqpur, Finite element modeling of coupled heat transfer, moisture transport and carbonation processes in concrete structures. Cem Concr Comp (2004) 26(1):57-73. https://doi.org/10.1016/S0958-9465(02)00125-7

[82] V. Baroghel-Bouny, M. Thiery, X. Wang, Modelling of isothermal coupled moisture-ion transport in cementitious materials. Cem Concr Res (2011) 41(8):828-841. https://doi.org/10.1016/j.cemconres.2011.04.001

[83] Z. Zhang, Modelling of sorption hysteresis and its effect on moisture transport within cementitious materials, Université Paris-Est, 2014.

[84] Z. Zhang, U. Angst, Modeling Anomalous Moisture Transport in Cement-Based Materials with Kinetic Permeability. Int J Molecular Sci (2020) 21(3):837. https://doi.org/10.3390/ijms21030837

[85] Methods of Measuring Moisture in Building Materials and Structures. State-of-the-Art Report of the RILEM Technical Committee 248MMB. L.-O. Nilsson (Ed.) Springer, 2018.

[86] R. Polder, C. Andrade, B. Elsener, $\varnothing$. Vennesland, J. Gulikers, R. Weidert, M. Raupach, RILEM TC 154-EMC: Electrochemical techniques for measuring metallic corrosion: "Test methods for on site measurement of resistivity of concrete". Mater Struct (2000) 33:603-611. https://doi.org/10.1007/BF02480599

[87] $\varnothing$. Vennesland, M. Raupach, C. Andrade, Recommendation of Rilem TC 154-EMC: "Electrochemical techniques for measuring corrosion in concrete" - measurements with embedded probes. Mater Struct (2007) 40(8):745-758. https://doi.org/10.1617/s11527-006-9219-4

[88] S. G. Millard, K. R. Gowers, Resistivity assessment of in-situ concrete: the influence of conductive and resistive layers. Proc Inst Civ Eng Struct Build (1992) 94(4):389-396. https://doi.org/10.1680/istbu.1992.21502

[89] M. Buettner, A. Ramirez, W. Daily, Electrical Resistance Tomography for Imaging Concrete Structures. Proc. Structural Materials Technology: an NDT Conference, San Diego, P. Hartbower and P. Stolarski (Eds.), Technomic Publishing Co., 1996,

[90] A. Seppänen, K. Karhunen, A. Lehikoinen, J. P. Kaipio, P. J. M. Monteiro, Electrical resistance tomography imaging of concrete. Proc. Concrete Repair, Rehabilitation and Retrofitting II, Proc. 2nd Int. Conf. on Concrete Repair, Rehabilitation and Retrofitting, Cape Town, South Africa, M. G. Alexander, H.-D. Beushausen, F. Dehn and P. Moyo (Eds.), CRC Press/Balkema, The Netherlands, 2008, 571-577.

[91] CONTECVET - A validated user's manual for assessing the residual life of concrete structures, DG Enterprise, CEC, https://www.ietcc.csic.es/wpcontent/uploads/1989/02/manual contecvet ingles.pdf 2001.
[92] Specification B12: Corrosion Monitoring of Reinforced concrete Structures. ISBN 978-3-940283-93-1, German Society for nondestructive Testing (DGZfP), 2018.

[93] H. Beushausen, N. Burmeister, The use of surface coatings to increase the service life of reinforced concrete structures for durability class XC. Mater Struct (2015) 48(4):1243-1252. https://doi.org/10.1617/s11527-013-0229-8

[94] X. Y. Pan, Z. G. Shi, C. J. Shi, T. C. Ling, N. Li, A review on surface treatment for concrete - Part 2: Performance. Constr Build Mater (2017) 133:81-90. https://doi.org/10.1016/i.conbuildmat.2016.11.128

[95] J. B. Aguiar, C. Junior, Carbonation of surface protected concrete. Constr Build Mater (2013) 49:478-483. https://doi.org/10.1016/j.conbuildmat.2013.08.058

[96] L. Schueremans, D. Van Gemert, S. Giessler, Chloride penetration in $\mathrm{RC}$-structures in marine environment - Long term assessment of a preventive hydrophobic treatment. Constr Build Mater (2007) 21(6):1238-1249. https://doi.org/10.1016/i.conbuildmat.2006.05.006

[97] L. Courard, V. Lucquiaud, Influence of hydrophobic treatments applications on the concrete carbonation delay. Proc. Durability of Building Materials and Components, RILEM publications, 2017, 403 404.

[98] P. Zhang, P. B. Li, H. Fan, H. S. Shang, S. Y. Guo, T. J. Zhao, Carbonation of Water Repellent-Treated Concrete. Adv Mater Sci Eng (2017) 2017. https://doi.org/10.1155/2017/1343947

[99] Q. Xu, S. L. Zhan, B. Z. Xu, H. Yang, X. Q. Qian, X. F. Ding, Effect of Isobutyl-triethoxy-silane Penetrative Protective Agent on the Carbonation Resistance of Concrete. J Wuhan Univ Technol (2016) 31(1):139-145. https://doi.org/10.1007/s11595-016-1343-6

[100] J. S. Mattila, Effect of water repellent coatings on the corrosion rate of reinforcement in carbonated concrete facades and balconies. COST C25-Sustainability of Constructions. Integrated Approach to Life-time Structural Engineering. ISBN 978-973-638-428-8. Proc. Timisoara seminar, Romania, 2009, 97-104.

[101] C. Andrade, N. Rebolledo, J. A. Morales, Surface Inhibitors for the Non-Invasive treatment of Corroded Structures. Proc. XIV DBMC 14th Int. Conf. on Durability of Building Materials and Components, Ghent University, Belgium., 2017, 